\title{
Estimating Changes in the Green Water Productivity of Cropping Systems in Northern Shaanxi Province in China's Loess Plateau
}

\author{
Jinping Wang ${ }^{1,2}$, Jinzhu Ma ${ }^{1, *}$, Afton Clarke-Sather ${ }^{2,3} \mathbb{D}$ and Jiansheng $Q \mathbf{u}^{2}$ \\ 1 College of Earth and Environmental Sciences, Lanzhou University, No. 222 South Tianshui Road, \\ Lanzhou 730000, China; wangjp@llas.ac.cn \\ 2 Lanzhou Library, Chinese Academy of Sciences, No, 8 Middle Tianshui Road, Lanzhou 730000, China; \\ afton@d.umn.edu (A.C.-S.); jsqu@lzb.ac.cn (J.Q.) \\ 3 Geography, Urban, Environment and Sustainability Studies, University of Minnesota Duluth, \\ Duluth, MN 55412, USA \\ * Correspondence: jzma@lzu.edu.cn; Tel.: +86-931-8912436; Fax: +86-931-8275743
}

Received: 3 August 2018; Accepted: 4 September 2018; Published: 6 September 2018

\begin{abstract}
Water shortages limit agricultural production in the world's arid and semi-arid regions. The Northern region of China's Shaanxi Province, in the Loess Plateau, is a good example. Raising the water productivity of rainfed grain production in this region is essential to increase food production and reduce poverty, thereby improving food security. To support efforts to increase crop water productivity (CWP), we accounted for limitations of most existing studies (experimental studies of specific crops or hydrological modeling approaches) by using actual field data derived from statistical reports of cropping patterns. We estimated the CWPs of nine primary crops grown in four counties in Northern Shaanxi from 1994 to 2008 by combining statistics on the cultivated area and yields with detailed estimates of evapotranspiration based on daily meteorological data. We further calculated both the caloric CWP of water (CCWP) and the CWP of productive water (i.e., water used for transpiration). We found that regional CWP averaged $6.333 \mathrm{~kg} \mathrm{~mm}^{-1} \mathrm{ha}^{-1}$, the CCWP was $17,683.81 \mathrm{cal} \mathrm{mm}^{-1} \mathrm{ha}^{-1}$, the CWP of productive green water was $8.837 \mathrm{~kg} \mathrm{~mm}^{-1} \mathrm{ha}^{-1}$, and the CCWP of productive green water was $24,769.07 \mathrm{cal} \mathrm{mm}^{-1} \mathrm{ha}^{-1}$. Corn, sorghum, and buckwheat had the highest CWP, and although potatoes had the largest planted area and relatively high CWP, they had a low CCWP.
\end{abstract}

Keywords: agricultural production; food security; water-use efficiency; crop water productivity; evapotranspiration

\section{Introduction}

\subsection{The Importance of Agricultural Crop Water Productivity}

Water shortages limit economic and social development in arid and semi-arid regions, including major grain-producing regions such as China's Loess Plateau. In recent years, water shortages have become some of the most serious challenges for agriculture around the world, and in the 21st century may jeopardize the world's ability to feed its growing population [1]. Crop production in arid and semi-arid areas is particularly and acutely limited by water shortages [2,3], since groundwater is also often limited. Water shortages are particularly serious in China, where dryland farming accounts for about one-third of the arable land. Roughly $40 \%$ of China's dryland farmland is located on the semi-arid Loess Plateau [4,5]. Improved crop water productivity (CWP, which represents the crop yield per unit area for each $1 \mathrm{~mm}$ of precipitation or irrigation), is essential for food security in this and 
other drylands [6]. In this study we estimated the CWPs of nine primary crops grown in four counties in Northern Shaanxi from 1994 to 2008 by combining statistics on the cultivated area and yields with detailed estimates of evapotranspiration based on daily meteorological data. We further calculated both the caloric crop water productivity (CCWP), and the CWP of productive water (i.e., water used for transpiration).

Proposals to increase agricultural production in arid and semi-arid regions often focus on irrigation. However, compared to alternatives such as choosing improved cultivars and optimizing nutrient management, increasing irrigation is often prohibitively expensive and may have serious adverse consequences such as salinization [7]. Improving the efficiency of rainfed agriculture presents an appealing option. Though previous studies have examined the roles of improved cultivars or superior landraces and of nutrient management in increasing CWP $[1,8]$, less research has examined the role of shifting to crops with higher CWP to improve the food security of dryland areas [9]. Increasing the utilization efficiency of water resources will help to improve local food self-sufficiency, thereby improving regional food security. Improved water productivity may also permit lower water withdrawals for irrigation, leaving more water for environmental purposes and reducing the risk of salinization [10].

\subsection{Background}

\subsubsection{Research on Green Water}

The proportion of global water consumption accounted for by agricultural water use is very large, with estimates ranging from $80 \%$ to $90 \%$ of global water use [1]. Such water can generally be divided into blue water, which enters abstractable surface and ground water flows, and green water, which is water that remains in the vadose zone and evaporates or is transpired by plants. Green water accounts for 55 to $80 \%$ of the total available freshwater supply in several regions of the world [11]. During the 20th century, gains in agricultural productivity during the green revolution came from improved plant breeds and fertilizer use, but irrigation also played an important role by mitigating water deficits in crop vegetation [1]. However, irrigation may be reaching its limits in the early 21 st century, both in terms of the available water and in terms of the amount of land that could be potentially irrigated [12]. Thus, further gains in global food production are likely to come through improvements in green water use rather than increased irrigation. Moreover, because agricultural green water use does not compete with water use by other economic sectors, such as domestic or industrial water use, it has a lower opportunity cost than blue water, and the use of green water for crop production generally has less-negative environmental externalities than the use of blue water [13].

\subsubsection{The Importance of Green Water CWP in China's Loess Plateau}

China is facing severe water shortages, particularly in North China, so the potential for improved green water management is highly significant. Li and Huang [14] showed that green water accounts for $57 \%$ of all the water that is potentially available for agricultural use in China. Water shortages are even more acute in the Loess Plateau, where there are few irrigation sources, difficult terrain, and limited and variable rainfall. As a result, the Loess Plateau has historically experienced relatively low agricultural productivity, and is primarily dependent on rainfed agriculture. The hilly terrain and the incised topography that result from wind and water erosion of the region's fine-grained soils, combined with the plateau's limited water resources to make rainfall the primary source of agricultural water.

Various methods are available to improve the CWP of crops in semi-arid environments, and a plethora of field experiments have shown this to be the case. Plastic film mulches can decrease unproductive evaporation from the soil and redirect the water towards productive transpiration, thereby increasing CWP. However, the economic returns have been mixed [15]. Nutrient management also has the potential to significantly improve CWP [1]. For example, Yan et al. found that Water Use 
Efficiency (WUE) was positively correlated with the ratio of nitrogen to phosphorus (N:P) in the leaves based on 132 plant samples distributed from the Qinling Mountains, located in the southern end of the Loess Plateau, to the Northern end of the plateau [16]. A less commonly examined approach is to encourage the cultivation of crops with higher average CWP, leading to high CWP at the farm level and possibly reducing costs compared to alternative technologies [9].

Most existing studies of CWP were based on field experiments and crop models [17-19]. Other studies have examined watershed-scale approaches using modeling tools such as the Soil and Water Assessment Tool (SWAT). Much less work has evaluated the CWP of agricultural systems at a regional level [9]. In this study we use the cultivated area of each crop and yield data from actual crops in the field alongside estimates of water use based on the FAO-56 methodology to estimate the regional CWP of agricultural systems [20,21].

\section{Materials and Methods}

We estimated the CWP in four representative counties with rain-fed agriculture in Northern Shaanxi Province from 1994 to 2008 by estimating consumptive water use from meteorological data and data on soil characteristics using the FAO-56 method [21]. We then compared the water use to the yield data from the county-level records. We calculated both the total amount of green water used and the productive green water, which we define as water that was used for transpiration rather than evaporation. We calculated both the gross CWP $\left(\mathrm{kg} \mathrm{mm}^{-1} \mathrm{ha}^{-1}\right)$ and the caloric crop water productivity (CCWP; $\mathrm{kcal} \mathrm{mm}^{-1} \mathrm{ha}^{-1}$ ) of green water in each year in each county. We estimated the proportion of each county's cropland occupied by each crop and the total area of each crop in the four counties, and calculated the weighted local grain production efficiency of green water for each crop and for the agricultural sector of each county as a whole.

\subsection{Study Site}

Northern Shaanxi Province is located near the center of China's Loess Plateau (Figure 1), a macro-region that encompasses parts of Shanxi, Ningxia, Shaanxi, Gansu, Qinghai, Inner Mongolia, and Henan provinces. We focused on four counties in Northern Shaanxi Province: Wuqi County, Zhidan County, Ansai County, and Zichang County. These counties were selected based on consistency in their data management practices during the study period and their high proportions of non-irrigated cropland. This region is a typical semi-arid area of rain-fed agriculture, with the majority of land in each county being unirrigated (Table 1).

Table 1. Total and non-irrigated areas of cropland in the study area in 2008.

\begin{tabular}{ccccc}
\hline & Wuqi & Zhidan & Ansai & Zichang \\
\hline Irrigated area (ha) & 3140.00 & 3255.73 & 200.00 & 2801.33 \\
Crop area (ha) & $18,860.00$ & $21,014.00$ & $35,502.00$ & $30,739.00$ \\
Proportion (\%) of non-irrigated area & 83.35 & 84.51 & 99.44 & 90.89 \\
\hline
\end{tabular}




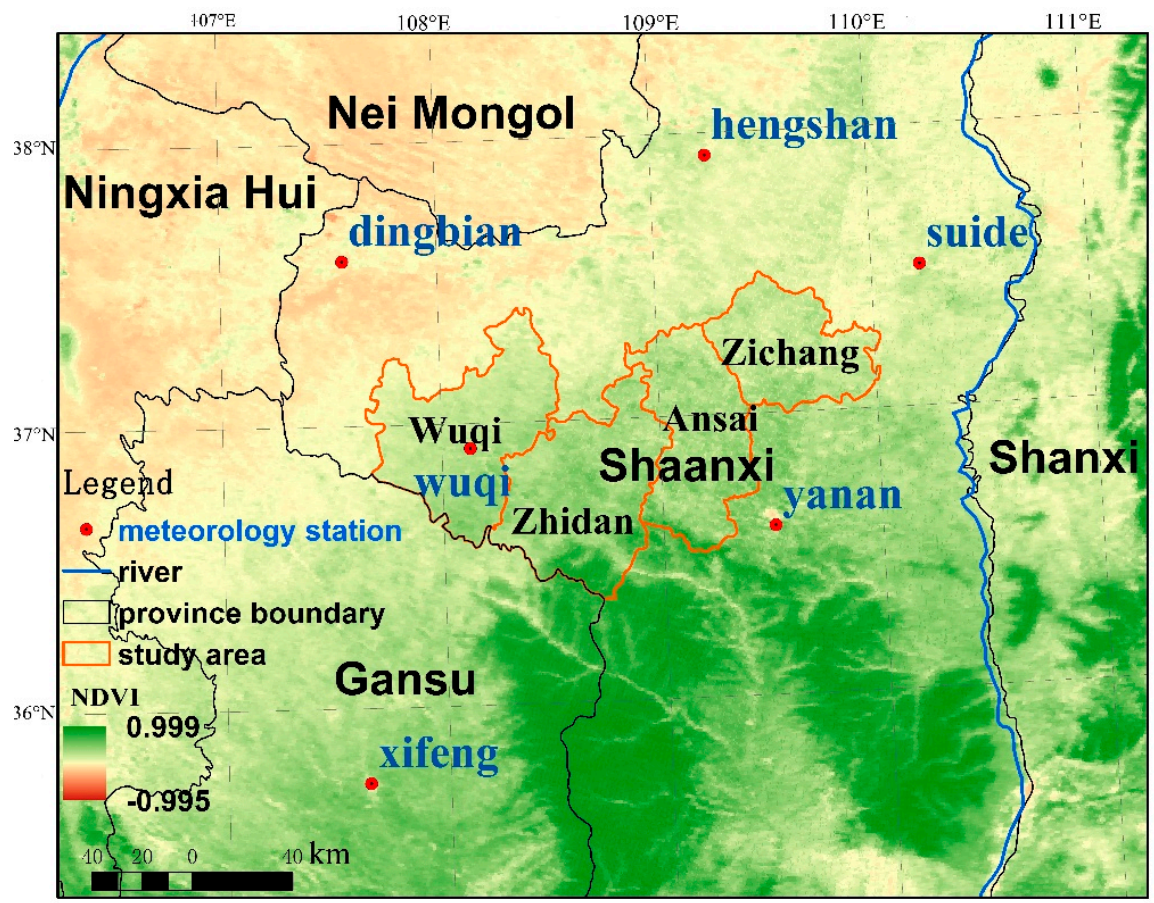

Figure 1. Location of the study area in Northern Shaanxi Province. NDVI means the normalized difference vegetation index.

\subsection{Data}

\subsubsection{Meteorological Data}

The meteorological data used in this study came from six weather stations located in and around the study area: Hengshan, Wuqi, Dingbian, Xifeng, Yan'an, and Suide. These sites are state-level meteorological stations of China and have strict specifications for the observation field according to the Specification for ground meteorological observations, including homogeneous and well-managed grass [22]. Meteorological parameters obtained from each station included the daily average temperature $\left(\mathrm{T}_{\text {mean }},{ }^{\circ} \mathrm{C}\right)$, maximum daily temperature $\left(\mathrm{T}_{\max },{ }^{\circ} \mathrm{C}\right)$, minimum daily temperature $\left(\mathrm{T}_{\min },{ }^{\circ} \mathrm{C}\right)$, average relative humidity $\left(\mathrm{RH}_{\text {mean }}, \%\right)$, average wind speed at a height of $10 \mathrm{~m}$ above the ground $\left(\mathrm{u}_{10}, \mathrm{~m} / \mathrm{sec}\right)$, hours of sunshine $(\mathrm{N}$, hours / day), daily precipitation $(\mathrm{P}, \mathrm{mm})$, and minimum daily relative humidity $\left(\mathrm{RH}_{\min }, \%\right)$.

Only one of the four counties of our study included the national meteorological station (Wuqi County). Therefore, to estimate meteorological parameters we used spatial interpolated of data from the national meteorological stations on the periphery of the research area. Since our research areas are counties bordering each other, we selected the inverse distance weighting method (IDW) for interpolation because it has been widely used in agriculture, marine and grassland animal husbandry applications, and because of it, it is simple in principle and relatively convenient to calculate for large data sets [23-25]:

$$
\begin{gathered}
\omega_{j, i}=\frac{\frac{1}{d_{i}}}{\sum_{i=1}^{n} \frac{1}{d_{i}}} \\
\mathrm{CPT}_{j}=\sum_{i=1}^{n} \omega_{i} \times \text { Station }_{i, j}
\end{gathered}
$$

where $\omega_{j, i}$ refers to the weighting coefficient of $i$ meteorological stations around $j$ county, $d_{i}$ is the distance from site $i$ to the center of county $j, \mathrm{CPT}_{j}$ refers to the meteorological parameter value of the geometric center of $j$ county, Station ${ }_{i, j}$ refers to data of $i$ meteorological station around $j$ County. 
We used IDW to interpolate the meteorological parameters at the geometric centers of each of the four counties, and these four points were used as a proxy to calculated the ET for each county. Table 2 shows the meteorological stations used for each county and the distance from the county's center to each of the surrounding stations.

Table 2. Reference meteorological stations of each county and the distance from the county's center to the surrounding stations.

\begin{tabular}{|c|c|c|c|c|c|c|}
\hline Distance(km) & Dinghian & Xifeng & Yan'an & Wugi & Henoshan & Suide \\
\hline Counties & Dimgorant & Aneng & Yan an & vuci & Hengsinan & surae \\
\hline Wuqi & 79.594 & 183.663 & & 47.780 & 111.336 & \\
\hline Zhidan & & 185.091 & 72.206 & & 100.326 & \\
\hline Ansai & & & 63.730 & 103.560 & & 95.522 \\
\hline Zichang & & & 100.203 & & 55.910 & 46.733 \\
\hline
\end{tabular}

\subsubsection{Crop Data}

Data on the area planted and yield for each crop came from the Statistical Yearbook of Yan'an [26], and focused on nine major food crops: Potato (Solanum tuberosum), corn (Zea mays), millet (Setaria italica), soybean (Glycine max), proso millet (Panicum miliaceum), wheat (Triticum aestivum), sorghum (Sorghum bicolor), buckwheat (Fagopyron esculentum), and mung bean (Vigna radiata). To calculate water losses, the FAO-56 method relies upon a crop coefficient that represents the difference in evapotranspiration between the crop and a reference evapotranspiration value. These values differ for each crop during four stages of growth. Based on local conditions, we determined the length of the growth cycle, the planting date, the start and end of each growth period, and the lengths of the four growth periods (Table 3). We defined the following periods: initial ( $\left.\mathrm{L}_{\mathrm{ini}}\right)$, development $\left(\mathrm{L}_{\mathrm{dev}}\right)$, stable growth $\left(\mathrm{L}_{\mathrm{mid}}\right)$, and maturation $\left(\mathrm{L}_{\text {late }}\right)$. Table 4 presents the crop yield data for the nine crops.

Table 3. Growth cycle parameters of the nine main crops in Northern Shaanxi Province.

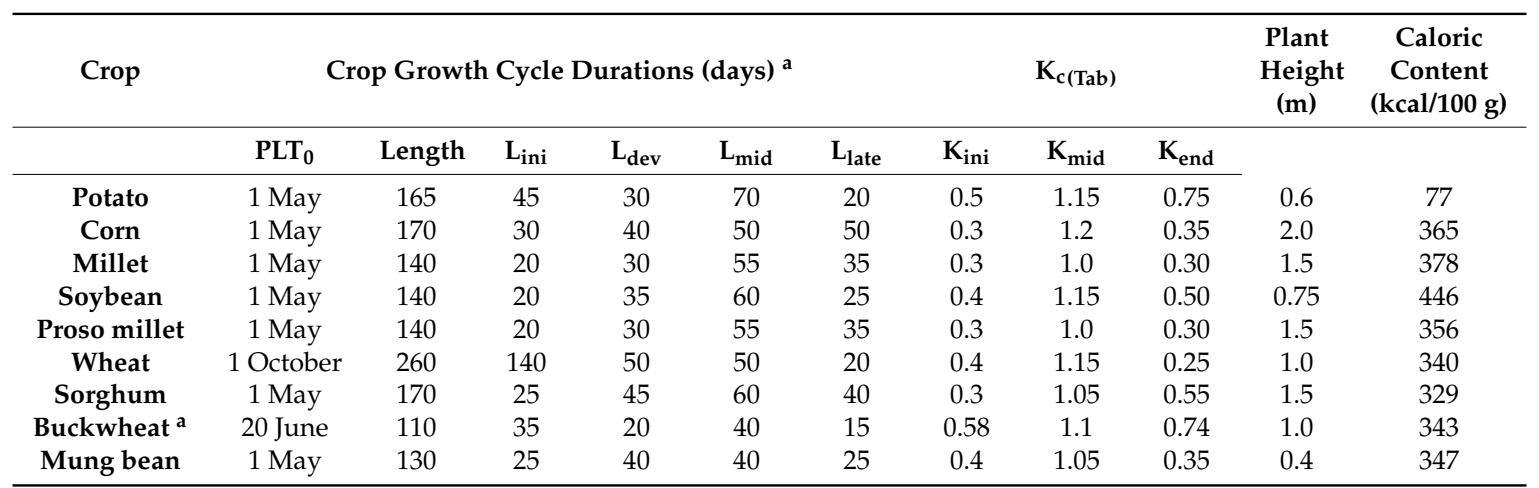

${ }^{a}$ Note: Growth durations and single-crop evapotranspiration coefficients $\left(\mathrm{K}_{\mathrm{c}}\right)$ are based on FAO data [27] and surveys of local farmers. $\mathrm{K}_{\mathrm{c}}$ and the mean maximum plant heights are for well-managed crops at these stages in sub-humid climates that are not under water stress $\left(\mathrm{RH}_{\min } \approx 45 \%\right.$, and a wind speed of $\approx 2 \mathrm{~m} / \mathrm{s}$ at a height $2 \mathrm{~m}$ above the ground) and are used with the FAO Penman-Monteith reference evapotranspiration $\left(\mathrm{ET}_{\mathrm{o}}\right)$. Buckwheat data [28] is based on Yan et al. work. Yield data source: Yanan Statistical Year Books [26]. Caloric content data source: USDA Definitions [29]. $\mathrm{PLT}_{0}$ is the planting date of the crop; Length is the total duration of the growth cycle; $\mathrm{L}_{\mathrm{ini}}$ is the early stage of crop growth; $\mathrm{L}_{\mathrm{dev}}$ is the development period; $\mathrm{L}_{\mathrm{mid}}$ is the stable period of crop growth; and $\mathrm{L}_{\text {late }}$ is the late stage of crop maturation. $\mathrm{K}_{\mathrm{c}(\mathrm{Tab})}$ represents the crop coefficient in this table, which is used in Equations (2) and (3). 
Table 4. Crop yields in the four counties. Source: Yanan Statistical Year Books [26].

\begin{tabular}{ccccc}
\hline Crops & Wuqi (kg/ha) & Zhidan (kg/ha) & Ansai (kg/ha) & Zichang (kg/ha) \\
\hline Potato & 2803.13 & 3173.33 & 2873.80 & 2275.20 \\
Corn & 6997.67 & 6465.00 & 5001.07 & 4691.53 \\
Millet & 1911.40 & 1963.60 & 1444.73 & 1523.80 \\
Soybean & 1651.93 & 2124.47 & 1355.73 & 1238.00 \\
Proso millet & 2425.29 & 1863.40 & 1272.40 & 1452.67 \\
Wheat & 1014.88 & 842.33 & 1102.33 & 902.86 \\
Sorghum & - & 6014.73 & 2891.50 & 2244.29 \\
Buckwheat & - & 1682.00 & 1214.75 & 951.50 \\
Mung bean & - & 1064.70 & 1055.83 & 956.00 \\
\hline
\end{tabular}

\subsection{CWP Calculations}

\subsubsection{Evapotranspiration}

Water consumption by a crop can be defined as the crop's actual transpiration: $\mathrm{ET}_{\text {adj }}$ [27]. In this study, we calculated $\mathrm{ET}_{\text {adj }}$ based on the FAO-56 dual cropcoefficient method. This approach consists of four steps: (1) Calculating reference evapotranspiration from meteorological data $\left(\mathrm{ET}_{\mathrm{o}}\right)$, (2) Calculating crop evapotranspiration $\left(\mathrm{ET}_{\mathrm{c}}\right.$ ) by creating growth-stage-based crop coefficient curves, (3) Accounting for situations of water depletion in the soil by calculating stress-induced evapotranspiration $\left(\mathrm{ET}_{\mathrm{adj}}\right)$, and (4) Partitioning evapotranspiration between evaporation and transpiration. These steps were conducted on a daily timescale during the growing season for each county.

(1) $\mathrm{ET}_{\mathrm{o}}$ calculation

There are many ways to estimate $\mathrm{ET}_{0}$, but their performance varies depending on the environment [30]. We chose the FAO-56 Penman Montieth formula for this study because it fully integrates many factors that affect evapotranspiration, and has shown estimates superior to those of other methods in a variety of contexts [30,31]. We calculated $\mathrm{ET}_{\mathrm{o}}$ using the $\mathrm{ET}_{\mathrm{o}}$ calculator software [32], which calculates $\mathrm{ET}_{\mathrm{o}}$ from meteorological data using the Penman-Monteith formula.

(2) Crop evapotranspiration under non-stressed conditions $\left(\mathrm{ET}_{\mathrm{C}}\right)$

Reference evapotranspiration is converted into crop evapotranspiration under non-stressed conditions $\left(\mathrm{ET}_{\mathrm{c}}\right)$ based on crop coefficients $\left(\mathrm{K}_{\mathrm{c}}\right)$ :

$$
\mathrm{ET}_{\mathrm{C}}=\mathrm{K}_{\mathrm{c}} \mathrm{ET}_{\mathrm{o}}
$$

where $\mathrm{ET}_{\mathrm{c}}$ is the crop's evapotranspiration under non-stressed conditions; $\mathrm{ET}_{\mathrm{O}}$ is the reference evapotranspiration; and $\mathrm{K}_{\mathrm{c}}$ is a crop coefficient that accounts for the crop's characteristics. $\mathrm{K}_{\mathrm{c}}$ was calculated on a daily basis by beginning with a reference $K_{c}$ value under standard conditions for each crop (Table 2). From these values, we constructed a $K_{c}$ curve for each crop that provided a daily reference value during the $\mathrm{L}_{\mathrm{dev}}$ and $\mathrm{L}_{\text {late }}$ stages. These values were then adjusted for daily meteorological conditions as follows: the crop coefficient for the initial growth stage $\left(\mathrm{Kc}_{\mathrm{ini}}\right)$ can be estimated from the $\mathrm{ET}_{\mathrm{O}}$ and the precipitation intervals during early crop growth according to the reference diagram or equation 7-3 from Annex 7 of FAO's drainage paper 56 [27]; $\mathrm{Kc}_{\mathrm{mid}}$ and $\mathrm{Kc}_{\mathrm{end}}$ can be calculated using the following equations:

$$
\begin{aligned}
& \mathrm{Kc}_{\text {mid }}=\mathrm{Kc}_{\text {mid }(\mathrm{Tab})}+\left(0.04\left(\mathrm{u}_{2}-2\right)-0.004\left(\mathrm{RH}_{\min }-45\right)\right) \times(\mathrm{h} / 3)^{0.3} \\
& \mathrm{~K}_{\text {end }}=\mathrm{Kc}_{\mathrm{end}(\mathrm{Tab})}+\left(0.04\left(\mathrm{u}_{2}-2\right)-0.004\left(\mathrm{RH}_{\text {min }}-45\right)\right) \times(\mathrm{h} / 3)^{0.3}
\end{aligned}
$$

where: $\mathrm{K} c_{\operatorname{mid}(\mathrm{Tab})}$ represents the values under standard conditions taken from Table $2 ; \mathrm{u}_{2}$ represents the mean daily wind speed at $2 \mathrm{~m}$ above the grass during the midseason growth stage $\left(\mathrm{m} \mathrm{s}^{-1}\right)$, for 
$1 \mathrm{~m} \mathrm{~s}^{-1} \leq \mathrm{u}_{2} \leq 6 \mathrm{~m} \mathrm{~s}^{-1} ; \mathrm{RH}_{\min }$ represents the mean daily minimum relative humidity during the mid-season growth stage (\%); and h represents the mean plant height during the mid-season stage $(\mathrm{m})$, taken from Table 2.

(3) Calculation of $\mathrm{ET}_{\text {adj }}$

Under stress (due to a water shortage in the soil), evapotranspiration ( $\mathrm{ET}_{\mathrm{adj}}$ ) will be less than under conditions with abundant water. $\mathrm{ET}_{\text {adj }}$ is calculated as follows:

$$
\mathrm{ET}_{\mathrm{adj}}=\mathrm{K}_{\mathrm{s}} \mathrm{ET}_{\mathrm{c}}=\mathrm{K}_{\mathrm{s}} \mathrm{K}_{\mathrm{c}} \mathrm{ET}_{\mathrm{o}}
$$

where $\mathrm{ET}_{\text {adj }}$ is the crop's evapotranspiration under water stress; $\mathrm{K}_{\mathrm{s}}$ is the crop coefficient under water stress; $\mathrm{K}_{\mathrm{cb}}$ is the ratio of the crop's transpiration to the reference evapotranspiration (i.e., $\mathrm{ET}_{\mathrm{adj}} / \mathrm{ET}_{\mathrm{o}}$ ); and $\mathrm{K}_{\mathrm{e}}$ is the ratio of the crop's evaporation to the reference evapotranspiration. $\mathrm{K}_{\mathrm{s}}$, which describes the effect of water stress on crop transpiration, can be derived from Equations (5) to (7), which account for the effects of soil moisture content:

$$
\begin{gathered}
\mathrm{K}_{\mathrm{s}}=\left(\mathrm{TAW}-\mathrm{D}_{\mathrm{ri}}\right) /(\mathrm{TAW}-\mathrm{RAW}) \\
\mathrm{RAW}=\mathrm{p} \times \mathrm{TAW} \\
\mathrm{TAW}=1000\left(\theta_{\mathrm{FC}}-\theta_{\mathrm{WP}}\right) \mathrm{Z}_{\mathrm{r}}
\end{gathered}
$$

where $\mathrm{K}_{\mathrm{s}}$ is a dimensionless transpiration reduction factor that depends on the available soil water (0 to 1), TAW is the total available soil water in the root zone $(\mathrm{mm}), \mathrm{D}_{\mathrm{ri}}$ is the root zone depletion of water $(\mathrm{mm}), \mathrm{RAW}$ is the readily available soil water in the root zone $(\mathrm{mm}), \mathrm{p}$ is the fraction of TAW that a crop can extract from the root zone without suffering water stress, $\theta_{\mathrm{FC}}$ is the water content at field capacity $\left(\mathrm{m}^{3} \mathrm{~m}^{-3}\right), \theta_{\mathrm{WP}}$ is the water content at the wilting point $\left(\mathrm{m}^{3} \mathrm{~m}^{-3}\right), \mathrm{Z}_{\mathrm{r}}$ is the rooting depth $(\mathrm{m})$, and when $\mathrm{D}_{\mathrm{ri}}<\mathrm{RAW}, \mathrm{K}_{\mathrm{s}}=1$ [27]. We calculated the water balance for each crop in each county throughout the growing season on a daily basis to determine whether $\mathrm{ET}_{\mathrm{adj}}$ or $\mathrm{ET}_{\mathrm{C}}$ should be used for that day. These daily calculations were then summed for the annual growing season to calculate total ET for each crop by county.

\section{(4) Partitioning Transpiration from Evaporation}

Green water consumption can be divided into two parts: Productive transpiration $\left(\mathrm{ET}_{\mathrm{cbs}}\right)$ and non-productive evaporation $\left(\mathrm{ET}_{\mathrm{e}}\right)$ from the soil and from water intercepted by canopy surfaces [33]. Productive green water (GW-P) is defined as the proportion of the green water that is released into the atmosphere through plant transpiration [34] and is therefore directly involved in the growth of crops:

$$
\begin{gathered}
\mathrm{K}_{\mathrm{c}}=\mathrm{K}_{\mathrm{cb}}+\mathrm{K}_{\mathrm{e}} \\
\mathrm{GW}-\mathrm{P}=\mathrm{ET}_{\mathrm{cbs}}=\mathrm{K}_{\mathrm{s}} \mathrm{K}_{\mathrm{cb}} \mathrm{ET}_{\mathrm{o}}
\end{gathered}
$$

where: $\mathrm{K}_{\mathrm{cb}}$ is the mean basal crop coefficient, and $\mathrm{K}_{\mathrm{e}}$ is the mean soil water evaporation coefficient.

Through the calculations in this section, we derived the average annual green water consumption for each crop and each county (Table 5). Combined with the yield data for each crop, this let us calculate CWP. 
Table 5. Annual average green water consumption by crops in the study from 1994 to 2008 .

\begin{tabular}{cllllllllll}
\hline County & Parameters a & Potato & Corn & Millet & Soybean & $\begin{array}{c}\text { Proso } \\
\text { Millet }\end{array}$ & Wheat & Sorghum & Buckwheat & $\begin{array}{c}\text { Mung } \\
\text { Bean }\end{array}$ \\
\hline \multirow{2}{*}{ Wuqi } & $G W_{\text {total }}(\mathbf{m m})$ & 366.32 & 421.68 & 361.84 & 348.88 & 361.81 & 265.37 & 425.90 & 270.33 & 307.04 \\
& $G W_{\text {prod }}(\mathbf{m m})$ & 276.54 & 321.24 & 286.89 & 278.28 & 288.09 & 115.05 & 323.71 & 125.71 & 228.85 \\
\hline \multirow{2}{*}{ Zhidan } & $G W_{\text {total }}(\mathbf{m m})$ & 378.74 & 429.07 & 373.82 & 363.72 & 373.82 & 279.33 & 439.19 & 274.33 & 321.32 \\
& $G W_{\text {prod }}(\mathbf{m m})$ & 278.35 & 318.91 & 291.98 & 285.50 & 291.98 & 116.60 & 331.10 & 127.46 & 236.40 \\
\hline \multirow{2}{*}{ Ansai } & $G W_{\text {total }}(\mathbf{m m})$ & 379.73 & 444.31 & 376.92 & 366.36 & 376.92 & 295.22 & 446.23 & 271.75 & 325.17 \\
& $G W_{\text {prod }}(\mathbf{m m})$ & 280.35 & 342.77 & 296.64 & 288.31 & 296.52 & 131.90 & 346.32 & 127.96 & 239.34 \\
\hline \multirow{2}{*}{ Zichang } & $G W_{\text {total }}(\mathbf{m m})$ & 369.17 & 437.06 & 371.14 & 359.47 & 371.19 & 296.40 & 431.53 & 265.30 & 318.88 \\
& $G W_{\text {prod }}(\mathbf{m m})$ & 274.71 & 340.40 & 293.38 & 282.79 & 292.23 & 118.96 & 337.56 & 126.11 & 234.07 \\
\hline
\end{tabular}

${ }^{a}$ Note: GW total represents the total green water consumed during crop growth; GW prod represents the productive green water (water directly consumed by transpiration during crop growth).

\subsubsection{Calculation of Crop Water Productivity}

We calculated the CWP of each crop by comparing the annual yield in each county to the annual $\mathrm{ET}_{\text {adj }}$ for that county. To determine the aggregate CWP for the agricultural system in each county, and for each individual crop across all counties, we weighted each crop or county by the proportional area of each crop:

$$
\begin{aligned}
\mathrm{CWP}_{\mathrm{i}} & =\sum_{\mathrm{j}=1}^{\mathrm{M}}\left(\frac{\mathrm{Y}_{\mathrm{i}, \mathrm{j}}}{\mathrm{GW}_{\mathrm{i}, \mathrm{j}}} \times \mathrm{PA}_{\mathrm{i}, \mathrm{j}}\right) \\
\mathrm{CWP} & =\sum_{\mathrm{i}=1}^{\mathrm{N}}\left(\frac{\mathrm{Y}_{\mathrm{i}, \mathrm{j}}}{\mathrm{GW}_{\mathrm{i}, \mathrm{j}}} \times \mathrm{PA}_{\mathrm{j}, \mathrm{i}}\right) \\
\mathrm{PA}_{\mathrm{i}, \mathrm{j}, \text { crop }} & =\mathrm{ha}_{\mathrm{i}, \mathrm{j}, \text { crop }} /\left(\sum_{\mathrm{j}}^{\mathrm{N}}\left(\mathrm{ha}_{\mathrm{i}, \mathrm{j}, \text { crop }}\right)\right) \\
\mathrm{PA}_{\mathrm{i}, \mathrm{j}, \text { area }} & =\mathrm{ha}_{\mathrm{i}, \mathrm{j}, \text { area }} /\left(\sum_{\mathrm{i}} \mathrm{M}^{\mathrm{M}}\left(\mathrm{ha}_{\mathrm{i}, \mathrm{j}, \text { area }}\right)\right)
\end{aligned}
$$

where: $\mathrm{CWP}_{\mathrm{i}}$ is the consumptive water productivity of crop $\mathrm{i}$ and $\mathrm{CWP}_{\mathrm{j}}$ is the consumptive water productivity of county $j$. $Y_{i, j}$ represents the crop yield for crop i in county $j$, and $G W_{i j}$ represents the corresponding green water use by crop $i$ in county $j$. $\mathrm{PA}_{\mathrm{i}, \mathrm{j}}$, is the proportion of crop $\mathrm{i}$ in county $\mathrm{j}$ calculated with respect to the entire study area, $\mathrm{PA}_{\mathrm{j}, \mathrm{i}, \mathrm{crop}}$ is the area proportion of crop $\mathrm{i}$ in county $j$ relative to the total area of crops $i$ in 4 county, $P_{j, i, \text { area }}$ is the area proportion of crop $i$ in county $j$ relative to nine crops in the $\mathrm{j}$ county. and $\mathrm{ha}_{\mathrm{i}, \mathrm{j}, \text {,rop }}$ and $\mathrm{ha}_{\mathrm{i}, \mathrm{j}, \text { area }}$ are the corresponding planting areas. $\mathrm{N}=9$ crops, and $\mathrm{M}=4$ counties.

We measured CWP in two ways: Gross CWP, in $\mathrm{kg} \mathrm{ha}^{-1} \mathrm{~mm}^{-1}$, and CCWP, in kcal ha ${ }^{-1} \mathrm{~mm}^{-1}$. The second value accounts for differences in the caloric content of the nine crops [29].

CCWP measures the ability of a food system to provide caloric intake, and is measured as follows:

$$
\begin{aligned}
& \mathrm{CCWP}_{\mathrm{i}}=\sum_{\mathrm{j}=1}^{\mathrm{M}}\left(\frac{\mathrm{Y}_{\mathrm{i}, \mathrm{j}} \times \mathrm{Cal}_{\mathrm{i}}}{\mathrm{GW}_{\mathrm{i}, \mathrm{j}}} \times \mathrm{PA}_{\mathrm{i}, \mathrm{j}}\right) \\
& \mathrm{CCWP}_{\mathrm{j}}=\sum_{\mathrm{i}=1}^{\mathrm{N}}\left(\frac{\mathrm{Y}_{\mathrm{i}, \mathrm{j}} \times \mathrm{Cal}_{\mathrm{i}}}{\mathrm{GW}_{\mathrm{i}, \mathrm{j}}} \times \mathrm{PA}_{\mathrm{j}, \mathrm{i}}\right)
\end{aligned}
$$

where: $\mathrm{i}$ represents the crop, $\mathrm{j}$ represents the county, $\mathrm{Cal}_{\mathrm{i}}$ is the caloric content of crop $\mathrm{i}$, and all other variables have the same meaning as in Equations (10) to (13).

Figure 2 summarizes the overall calculation process. The gross CWP of productive water (CWP-P) and the caloric CWP of productive water (CCWP-P) were calculated similarly to CWP and CCWP, but after substituting $\mathrm{ETc}_{\mathrm{cbs}}$ for $\mathrm{ETc}_{\mathrm{adj}}$. 


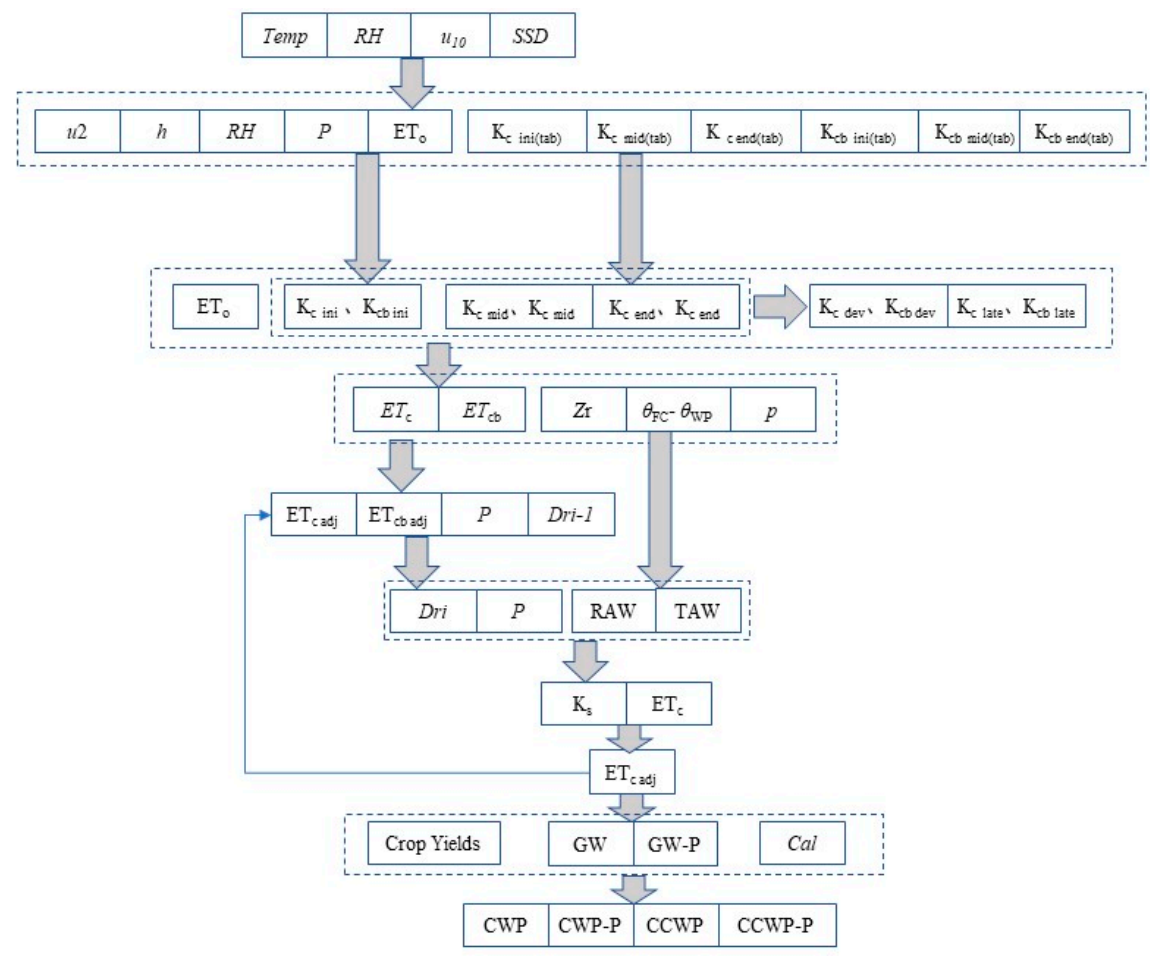

Figure 2. Calculation process for determining the green water consumption, crop water productivity (CWP), and caloric crop water productivity (CCWP). Abbreviations: Temp means the daily maximum, minimum, and average temperatures $\left({ }^{\circ} \mathrm{C}\right)$; $\mathrm{RH}$ means the mean and minimum relative humidity $(\%)$; $\mathrm{u} 10$ means the wind speed above the ground (m/s); SSD means the sunshine duration per day (hours); $h$ means the maximum crop height $(\mathrm{m})$; P means precipitation; Cal means the caloric content of the crop (kcal); RAW is the readily available soil water in the root zone (mm); TAW is the total available soil water in the root zone $(\mathrm{mm})$; $\mathrm{p}$ is the fraction of TAW that a crop can extract from the root zone without suffering water stress; $\theta \mathrm{FC}$ is the water content at field capacity $\left(\mathrm{m}^{3} \mathrm{~m}^{-3}\right)$; $\theta \mathrm{WP}$ is the water content at the wilting point $\left(\mathrm{m}^{3} \mathrm{~m}^{-3}\right)$; $\mathrm{Zr}$ is the rooting depth $(\mathrm{m})$; and Dri is the root zone depletion of water $(\mathrm{mm})$.

\section{Results}

\subsection{Average CWP of Crops and Counties}

The simple unweighted annual average green water CWP of the nine food crops was $5.882 \mathrm{~kg}$ $\mathrm{mm}^{-1} \mathrm{ha}^{-1}$, and the average CWP-P was $8.537 \mathrm{~kg} \mathrm{~mm}^{-1} \mathrm{ha}^{-1}$; The average CCWP of green water was $17683.81 \mathrm{cal} \mathrm{mm}^{-1} \mathrm{ha}^{-1}$, and the CCWP-P was $24,769.07 \mathrm{cal} \mathrm{mm}^{-1} \mathrm{ha}^{-1}$. In other words, 0.5882 gross $\mathrm{kg}$ of grain, equivalent to 1897 calories, could be produced from $1 \mathrm{t}$ of green water, and 0.8537 gross $\mathrm{kg}$ of grain, equivalent to 2759 calories, could be produced from $1 \mathrm{t}$ of productive green water.

From the perspective of gross grain output (Figure 3a), the variation among the nine crops is significant. Corn had the highest green water productivity $\left(12.370 \mathrm{~kg} \mathrm{~mm}^{-1} \mathrm{ha}^{-1}\right)$, which was nearly four times that of mung bean $\left(3.329 \mathrm{~kg} \mathrm{~mm}^{-1} \mathrm{ha}^{-1}\right)$, which had the lowest productivity. In addition to corn, potato, sorghum, and buckwheat had a high CWP. Mung bean and wheat, which had the lowest CWP, also accounted for the lowest proportions of cultivated area in the study area: The average proportion of the area cultivated with mung bean was $0.7 \%$ (the lowest proportion of the nine grain crops), and between 1994 and 2008, the area cultivated with wheat decreased by $98 \%$.

Crops also varied significantly in CWP-P (Figure 3a), in ways that were not directly predictable from CWP. The CWP-P of buckwheat and wheat were more than twice their CWP values, whereas the CWP-P of the other crops showed more modest increases of 10 to $25 \%$. 
Based on CCWP and CCWP-P (Figure 3c), corn remained the most efficient crop (CCWP $45150.71 \mathrm{kcal} \mathrm{mm}^{-1} \mathrm{ha}^{-1}$; CCWP-P $59184.91 \mathrm{kcal} \mathrm{mm}^{-1} \mathrm{ha}^{-1}$ ). As in the CWP and CWP-P analyses, sorghum had the second-highest CCWP and CCWP-P. However, despite having some of the highest CWP and CWP-P values, potato had the lowest CCWP and CCWP-P, with values of only 5423.00 and $7312.12 \mathrm{kcal} \mathrm{mm}^{-1} \mathrm{ha}^{-1}$, respectively, which are equivalent to 12.0 and $12.4 \%$ of the value for corn.

The counties also varied in their productivity (Figure $3 b, d$ ). The simple unweighted average annual CWP in the four counties was $6.586 \mathrm{kcal} \mathrm{mm}^{-1} \mathrm{ha}^{-1}$, and CWP-P was $9.18 \mathrm{kcal} \mathrm{mm}^{-1} \mathrm{ha}^{-1}$. The CCWP in the four counties averaged $18,472.52 \mathrm{kcal} \mathrm{mm}^{-1} \mathrm{ha}^{-1}$, and CCWP-P averaged $25,824.12 \mathrm{kcal} \mathrm{mm}^{-1} \mathrm{ha}^{-1}$. Wuqi County had the highest CWP $\left(7.715 \mathrm{~kg} \mathrm{~mm}^{-1} \mathrm{ha}^{-1}\right)$, and Ansai County had the lowest $\left(5.760 \mathrm{~kg} \mathrm{~mm}^{-1} \mathrm{ha}^{-1}\right)$. CCWP followed a slightly different pattern, with the highest value in Zhidan County $\left(22,771.81 \mathrm{kcal} \mathrm{mm}^{-1} \mathrm{ha}^{-1}\right)$, but the lowest value was still in Ansai County $\left(16,723.60 \mathrm{kcal} \mathrm{mm}^{-1} \mathrm{ha}^{-1}\right)$. The trends were nearly the same for the productive values, except that Zichang County had the lowest CCWP-P (Figure 3d).
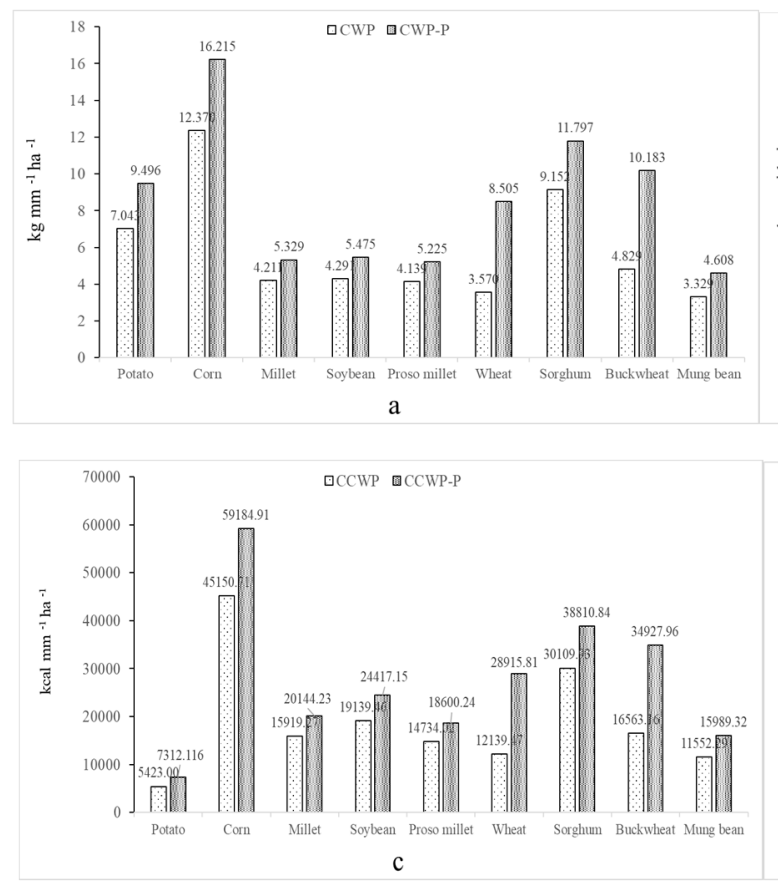
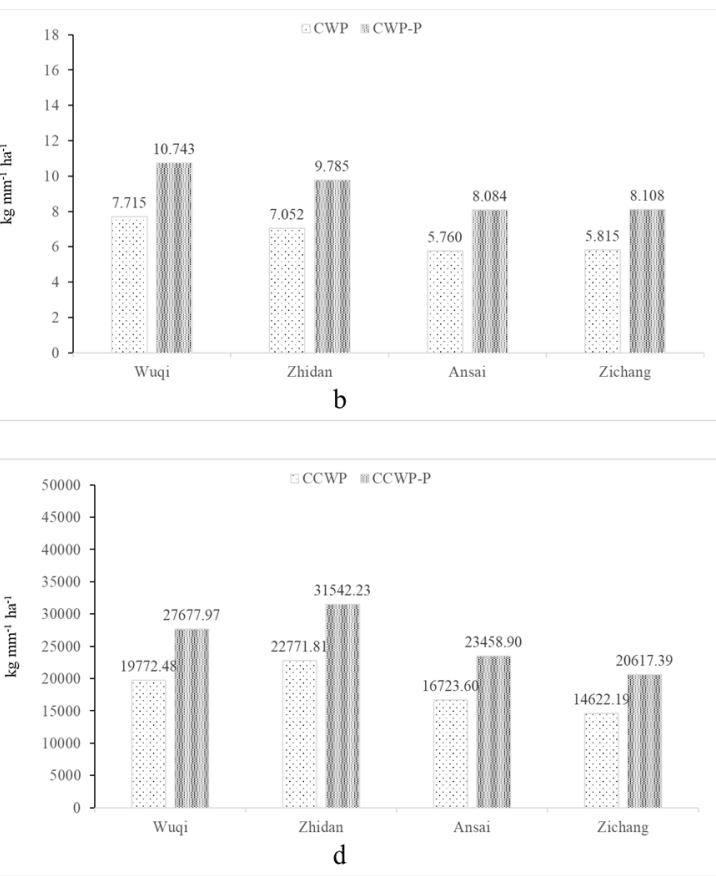

Figure 3. Simple unweighted average annual $(\mathbf{a}, \mathbf{b})$ crop water productivity (CWP) and CWP for productive green water (CWP-P) and (c,d) caloric crop water productivity (CCWP) and CCWP for productive green water (CCWP-P) for $(\mathbf{a}, \mathbf{c})$ the nine crops and $(\mathbf{b}, \mathbf{d})$ the four counties in the study region.

\subsection{Weighted Productivity of Green Water in the Agricultural System over Time}

Because the proportions of the total area planted with each crop vary throughout the study region and over time, it was necessary to use an area-weighted summation method to calculate the overall CWP and CCWP of agricultural systems in each county throughout the study period. Figure 4 shows the annual changes in the area-weighted CWP and CWP-P for the nine major food crops from 1994 to 2008 for the entire study area. These values were calculated using Equation (10). Table 6 provides the values used to create these graphs. Figure 5 shows the area-weighted CCWP and CCWP-P for the nine crops, and Table 7 shows the data used to create these graphs. 

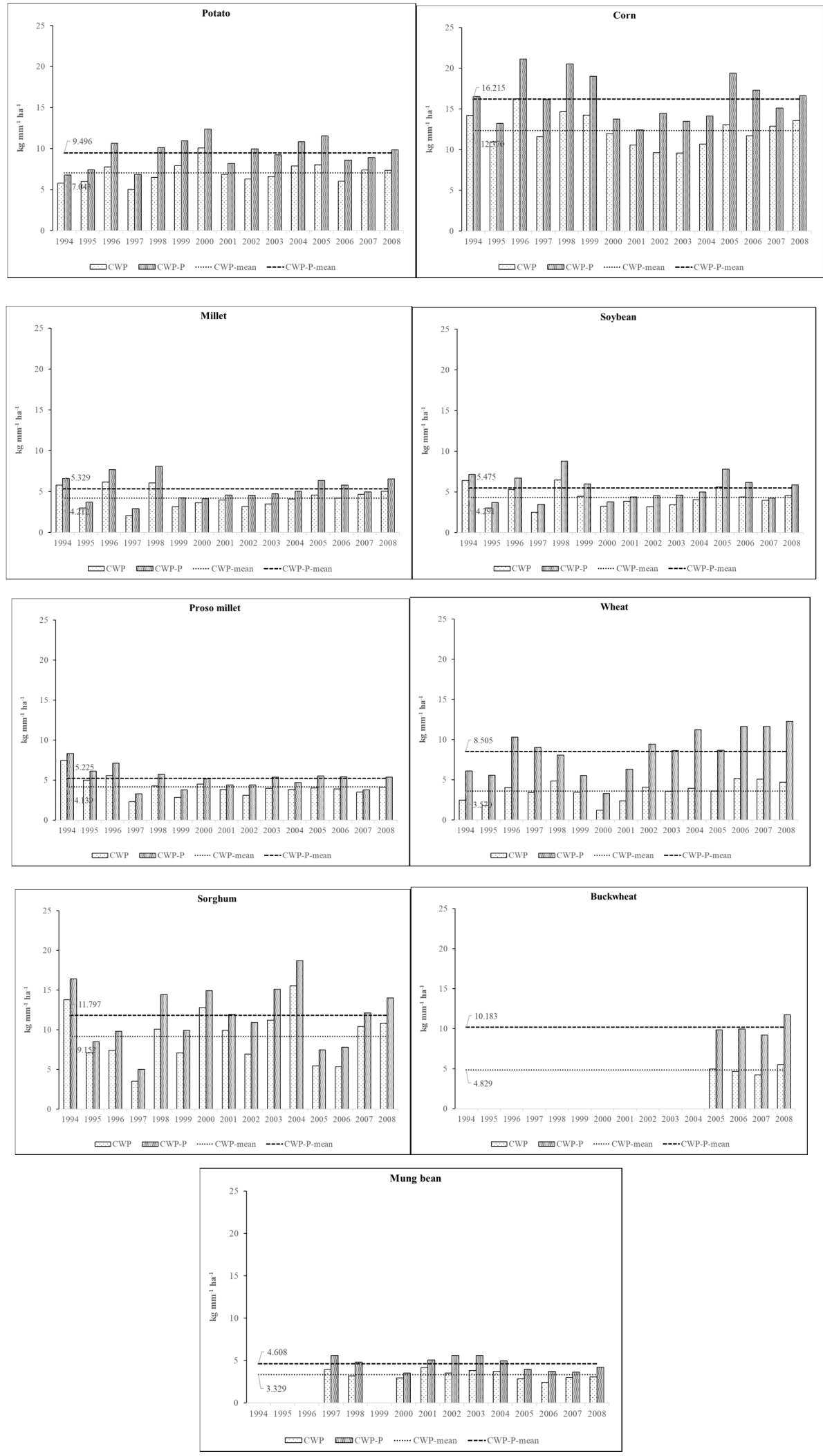

Figure 4. Annual changes in the area-weighted crop water productivity (CWP) and productive green-water caloric crop water productivity (CWP-P) for the nine crops in the study area. Horizontal dashed lines represent the overall mean values for the study period. 
Table 6. The area-weighted crop green water productivity (CWP, $\left.\mathrm{kg} \mathrm{mm}^{-1} \mathrm{ha}^{-1}\right)$ and productive green water crop productivity $\left(\mathrm{CWP}-\mathrm{P}, \mathrm{kg} \mathrm{mm}^{-1}\right.$ ha $\left.{ }^{-1}\right)$ for the nine main crops in the study area from 1994 to 2008 , and the mean value for the study period.

\begin{tabular}{|c|c|c|c|c|c|c|c|c|c|c|c|c|c|c|c|c|c|}
\hline Crops & & 1994 & 1995 & 1996 & 1997 & 1998 & 1999 & 2000 & 2001 & 2002 & 2003 & 2004 & 2005 & 2006 & 2007 & 2008 & Mean \\
\hline \multirow{2}{*}{ Potato } & CWP & 5.818 & 6.005 & 7.766 & 5.064 & 6.500 & 7.940 & 10.092 & 6.881 & 6.284 & 6.611 & 7.883 & 8.026 & 6.032 & 7.390 & 7.350 & 7.043 \\
\hline & CWP-P & 6.783 & 7.422 & 10.673 & 6.877 & 10.124 & 10.966 & 12.386 & 8.196 & 9.977 & 9.254 & 10.827 & 11.547 & 8.621 & 8.928 & 9.864 & 9.496 \\
\hline \multirow[b]{2}{*}{ Corn } & CWP & 14.218 & 10.944 & 16.246 & 11.588 & 14.669 & 14.262 & 11.955 & 10.561 & 9.637 & 9.601 & 10.667 & 13.068 & 11.697 & 12.887 & 13.548 & 12.370 \\
\hline & CWP-P & 16.527 & 13.210 & 21.126 & 16.136 & 20.531 & 19.013 & 13.742 & 12.443 & 14.480 & 13.475 & 14.123 & 19.388 & 17.304 & 15.105 & 16.623 & 16.215 \\
\hline \multirow{2}{*}{ Millet } & CWP & 5.814 & 2.995 & 6.185 & 2.059 & 6.060 & 3.140 & 3.652 & 3.993 & 3.193 & 3.493 & 4.089 & 4.587 & 4.193 & 4.666 & 5.054 & 4.211 \\
\hline & CWP-P & 6.578 & 3.705 & 7.696 & 2.932 & 8.117 & 4.235 & 4.121 & 4.600 & 4.536 & 4.732 & 5.026 & 6.354 & 5.798 & 4.948 & 6.560 & 5.329 \\
\hline \multirow{2}{*}{ Soybean } & CWP & 6.389 & 3.024 & 5.300 & 2.507 & 6.475 & 4.458 & 3.263 & 3.846 & 3.160 & 3.437 & 4.033 & 5.611 & 4.389 & 3.952 & 4.527 & 4.291 \\
\hline & CWP-P & 7.133 & 3.720 & 6.695 & 3.482 & 8.782 & 5.964 & 3.777 & 4.385 & 4.520 & 4.620 & 5.000 & 7.781 & 6.167 & 4.225 & 5.868 & 5.475 \\
\hline \multirow{2}{*}{ Millet } & CWP & 7.451 & 4.972 & 5.562 & 2.304 & 4.286 & 2.822 & 4.504 & 3.801 & 3.095 & 3.962 & 3.797 & 4.014 & 3.882 & 3.494 & 4.135 & 4.139 \\
\hline & CWP-P & 8.338 & 6.110 & 7.113 & 3.279 & 5.695 & 3.773 & 5.158 & 4.379 & 4.380 & 5.356 & 4.697 & 5.535 & 5.403 & 3.773 & 5.383 & 5.225 \\
\hline \multirow[b]{2}{*}{ Wheat } & CWP & 2.441 & 1.781 & 4.038 & 3.398 & 4.823 & 3.452 & 1.185 & 2.388 & 4.099 & 3.544 & 3.943 & 3.570 & 5.159 & 5.048 & 4.688 & 3.570 \\
\hline & CWP-P & 6.102 & 5.569 & 10.293 & 8.996 & 8.051 & 5.535 & 3.301 & 6.303 & 9.435 & 8.623 & 11.203 & 8.658 & 11.638 & 11.613 & 12.252 & 8.505 \\
\hline \multirow{2}{*}{ Sorghum } & CWP & 13.783 & 7.075 & 7.424 & 3.512 & 10.055 & 7.066 & 12.812 & 9.911 & 6.915 & 11.206 & 15.530 & 5.435 & 5.323 & 10.398 & 10.832 & 9.152 \\
\hline & CWP-P & 16.388 & 8.473 & 9.819 & 5.001 & 14.417 & 9.929 & 14.912 & 11.929 & 10.909 & 15.115 & 18.691 & 7.435 & 7.784 & 12.126 & 14.021 & 11.797 \\
\hline \multirow{2}{*}{ Buckwheat } & CWP & & & & & & & & & & & & 4.959 & 4.643 & 4.227 & 5.486 & 4.829 \\
\hline & CWP-P & & & & & & & & & & & & 9.829 & 9.956 & 9.214 & 11.733 & 10.183 \\
\hline \multirow{2}{*}{ Mung bean } & CWP & & & & 3.951 & 3.189 & & 2.970 & 4.162 & 3.511 & 3.830 & 3.728 & 2.821 & 2.410 & 2.980 & 3.070 & 3.329 \\
\hline & CWP-P & & & & 5.614 & 4.794 & & 3.539 & 5.078 & 5.595 & 5.621 & 4.948 & 3.992 & 3.697 & 3.621 & 4.187 & 4.608 \\
\hline \multirow{2}{*}{$\begin{array}{l}\text { Weighted } \\
\text { average }\end{array}$} & CWP & 5.755 & 4.239 & 7.019 & 4.490 & 7.263 & 6.287 & 6.521 & 5.532 & 5.426 & 6.193 & 6.993 & 7.785 & 6.404 & 7.342 & 7.740 & 6.333 \\
\hline & CWP-P & 7.516 & 6.106 & 10.603 & 7.436 & 10.602 & 8.729 & 8.169 & 7.206 & 8.553 & 8.816 & 9.317 & 11.356 & 9.338 & 8.695 & 10.120 & 8.837 \\
\hline
\end{tabular}



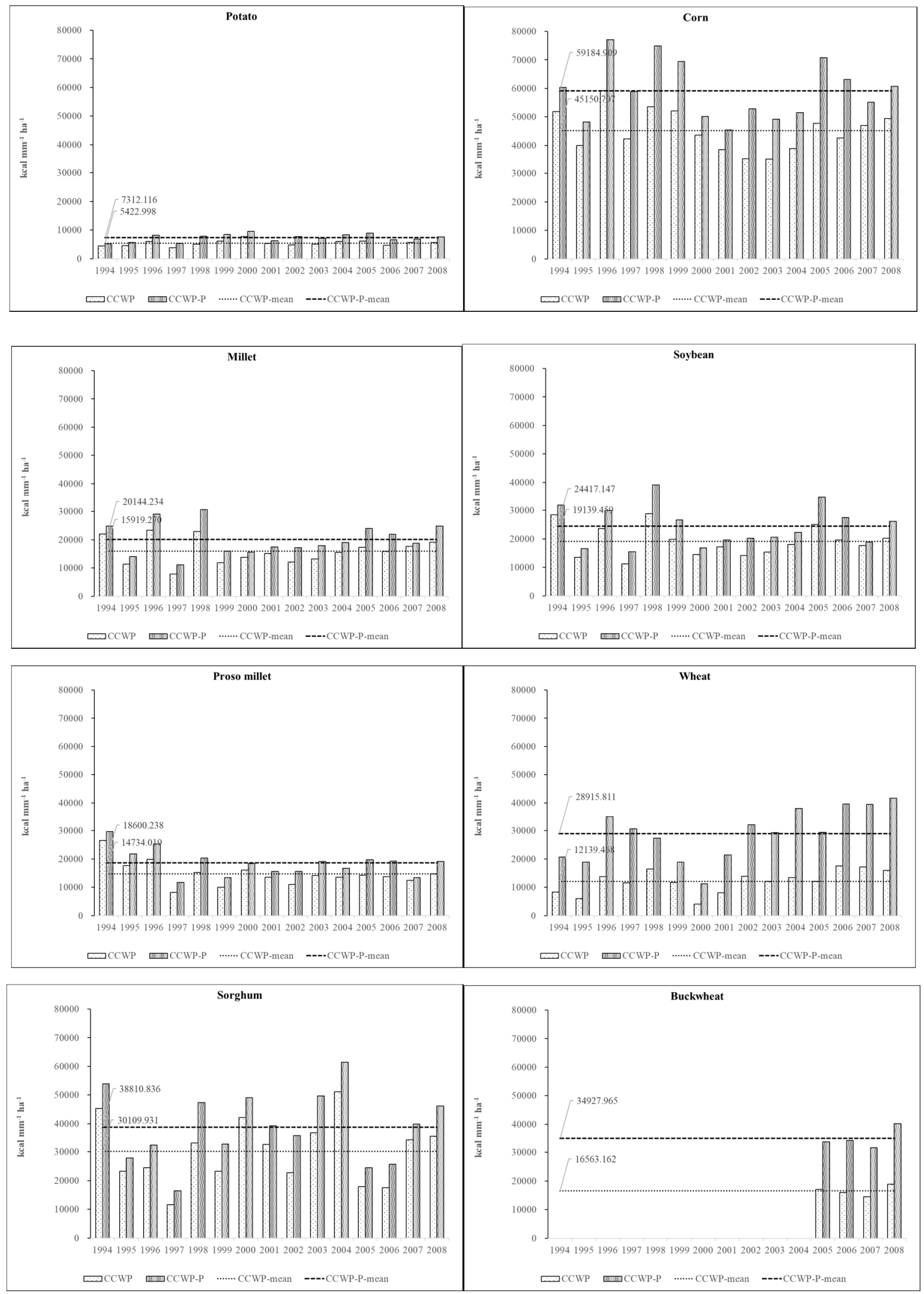

Figure 5. Cont. 


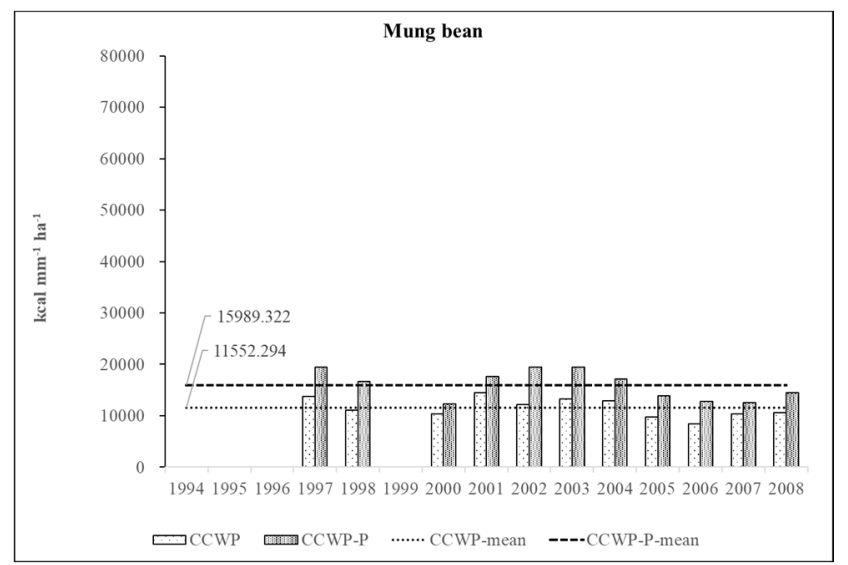

Figure 5. Annual changes in the area-weighted caloric crop water productivity (CCWP) and productive caloric green water crop water productivity (CCWP-P) for the nine crops in the study area. Horizontal dashed lines represent the overall mean values for the study period. 
Table 7. The area-weighted caloric crop green water productivity (CCWP, $\mathrm{kcal} \mathrm{mm}^{-1} \mathrm{ha}^{-1}$ ) and productive caloric green water productivity (CCWP-P, $\mathrm{kcal} \mathrm{mm}^{-1} \mathrm{ha}^{-1}$ ) for the nine main crops in the study area from 1994 to 2008 , and the mean value for the study period.

\begin{tabular}{|c|c|c|c|c|c|c|c|c|c|c|c|c|c|c|c|c|c|}
\hline Crops & & 1994 & 1995 & 1996 & 1997 & 1998 & 1999 & 2000 & 2001 & 2002 & 2003 & 2004 & 2005 & 2006 & 2007 & 2008 & Mean \\
\hline \multirow{2}{*}{ Potato } & 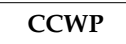 & 80.18 & 4624.23 & 5979.78 & 3899.41 & 5005.11 & 6113.95 & 7770.99 & 5298.21 & 4838.51 & 5090.11 & 6069.87 & 6179.76 & 4644.95 & 5690.49 & 5659.40 & 5423.00 \\
\hline & CCV & 95 & 5714.91 & 8218.09 & 5294.91 & 7795.36 & 8443.66 & 9537.40 & 6310.56 & 7682.35 & 7125.41 & 8337.05 & 8891.50 & 6638.04 & 6874.61 & 7594.93 & 7312.12 \\
\hline \multirow[b]{2}{*}{ Corn } & WP & 893.93 & $39,946.37$ & $59,296.96$ & $42,297.51$ & $53,543.67$ & $52,056.08$ & $43,634.62$ & $38,549.26$ & $35,176.26$ & $35,045.43$ & $38,935.86$ & $47,699.35$ & $42,695.33$ & $47,039.11$ & $49,450.84$ & $45,150.71$ \\
\hline & CCWP-P & $60,323.11$ & $48,217.22$ & $77,108.11$ & $58,897.26$ & $74,937.34$ & $69,396.75$ & $50,158.02$ & $45,416.86$ & $52,852.89$ & $49,185.03$ & $51,547.75$ & $70,765.68$ & $63,161.03$ & $55,131.69$ & $60,674.89$ & $59,184.91$ \\
\hline \multirow[b]{2}{*}{ Millet } & CWP & 4 & .41 & $23,379.09$ & 7784.41 & $22,908.18$ & $11,869.17$ & $13,804.28$ & $15,092.34$ & $12,069.01$ & $13,202.26$ & $15,454.68$ & $17,338.15$ & $15,848.72$ & $17,638.19$ & $19,102.84$ & $15,919.27$ \\
\hline & CCWP-P & $24,863.12$ & $14,003.91$ & $29,091.75$ & $11,082.61$ & $30,683.37$ & $16,010.18$ & $15,576.87$ & $17,388.04$ & $17,145.85$ & $17,885.51$ & $18,998.83$ & $24,019.41$ & $21,915.95$ & $18,701.64$ & $24,796.47$ & $20,144.23$ \\
\hline \multirow{2}{*}{ Soybean } & CCWP & 6 & 12 & .03 & .84 & 80.72 & $19,882.40$ & $14,554.73$ & $17,154.62$ & $14,094.10$ & $15,329.68$ & 17, & 3.39 & 3.97 & 5.06 & 19 & 39.46 \\
\hline & CCWP-P & $31,814.13$ & $16,591.59$ & $29,861.59$ & $15,531.86$ & $39,167.76$ & $26,597.88$ & $16,846.04$ & $19,558.08$ & $20,160.67$ & $20,607.27$ & $22,299.82$ & $34,701.40$ & $27,503.57$ & $18,843.63$ & $26,171.91$ & $24,417.15$ \\
\hline \multirow{2}{*}{ Millet } & & 2 & 9 & 7 & 82 & 20 & 10 & 48 & 0 & & 77 & 13 & & 45 & & & .02 \\
\hline & CCWP-P & $29,682.10$ & $21,753.08$ & $25,321.62$ & $11,672.11$ & $20,274.71$ & $13,431.97$ & $18,362.43$ & $15,587.71$ & $15,594.56$ & $19,065.77$ & $16,722.94$ & $19,702.97$ & $19,236.43$ & $13,431.44$ & $19,163.72$ & $18,600.24$ \\
\hline \multirow{2}{*}{ Wheat } & & 8 & & 93 & 00 & & .35 & & & & & & & & & & 9.47 \\
\hline & CCWP-P & $20,748.30$ & $18,934.53$ & $34,995.84$ & $30,585.27$ & $27,372.44$ & $18,818.21$ & $11,222.90$ & $21,430.00$ & $32,077.89$ & $29,318.16$ & $38,089.34$ & $29,436.78$ & $39,568.17$ & $39,483.82$ & $41,655.52$ & $28,915.81$ \\
\hline \multirow{2}{*}{ Sorghum } & & 9 & 23,2 & 88 & 11,5 & 33,0 & 89 & 42, & 32, & & 36,8 & 51, & 81 & 82 & 34 & 80 & 93 \\
\hline & CCWP-P & $53,915.74$ & $27,874.63$ & $32,303.63$ & $16,452.83$ & $47,433.32$ & $32,666.17$ & $49,059.42$ & $39,246.68$ & $35,891.73$ & $49,729.75$ & $61,493.56$ & $24,462.07$ & $25,609.41$ & $39,893.72$ & $46,129.88$ & $38,810.84$ \\
\hline \multirow[b]{2}{*}{ Buckwheat } & $\mathrm{C}$ & & & & & & & & & & & & 9.65 & .73 & 14 & 29 & 3.16 \\
\hline & CCWP-P & & & & & & & & & & & & $33,714.49$ & $34,148.48$ & $31,603.85$ & $40,245.04$ & $34,927.96$ \\
\hline \multirow{2}{*}{ Mung bean } & CCW & & & & & 11,0 & & & & & & & 97,8 & 83, & 59 & 51 & 2.29 \\
\hline & CCWP-P & & & & $19,481.62$ & $16,633.47$ & & $12,281.09$ & $17,621.44$ & $19,414.18$ & $19,506.06$ & $17,170.48$ & $13,852.64$ & $12,827.67$ & $12,566.11$ & $14,527.79$ & $15,989.32$ \\
\hline \multirow{2}{*}{$\begin{array}{c}\text { Weighted } \\
\text { average }\end{array}$} & CCWI & & & 0 & 13 & 5 & & 15 & 15 & 14 & 15 & 17 & 12 & 15 & 76 & 13 & 81 \\
\hline & CCWP-P & $24,838.89$ & $17,948.84$ & $32,634.50$ & $23,194.04$ & $34,602.15$ & $26,842.40$ & $19,615.38$ & $20,478.06$ & $23,076.57$ & $22,768.73$ & $23,494.08$ & $28,909.58$ & $25,973.77$ & $21,681.61$ & $25,477.50$ & $24,769.07$ \\
\hline
\end{tabular}


Figure 6a shows the changes over time in the overall CWP (all crops combined) for the study area from 1994 to 2008. CWP ranged between 4.0 and $8.0 \mathrm{~kg} \mathrm{~mm}^{-1} \mathrm{ha}^{-1}$, with the lowest and highest values in 1995 (4.239 $\left.\mathrm{kg} \mathrm{mm}^{-1} \mathrm{ha}^{-1}\right)$ and $2005\left(7.785 \mathrm{~kg} \mathrm{~mm}^{-1} \mathrm{ha}^{-1}\right)$, respectively, and with no overall trend over time. The annual average CWP during this period was $6.333 \mathrm{~kg} \mathrm{~mm}^{-1} \mathrm{ha}^{-1}$. CWP-P followed the same pattern, and was significantly positively correlated with CWP $(\mathrm{r}=0.8683$, $p<0.05$ ). CWP-P averaged $8.837 \mathrm{~kg} \mathrm{~mm}^{-1} \mathrm{ha}^{-1}$, and ranged from $6.106 \mathrm{~kg} \mathrm{~mm}^{-1} \mathrm{ha}^{-1}$ in 1995 to $11.356 \mathrm{~kg} \mathrm{~mm}^{-1} \mathrm{ha}^{-1}$ in 2005. Figure $6 \mathrm{~b}$ shows the corresponding changes in CCWP and CCWP-P. CCWP averaged $17,683.81 \mathrm{~kg} \mathrm{~mm}^{-1} \mathrm{ha}^{-1}$ during the study period, versus $24,769.07 \mathrm{~kg} \mathrm{~mm}^{-1} \mathrm{ha}^{-1}$ for CCWP-P. While the overall trend was similar to that for CWP, lower CCWP values are present near the end of the study period, likely driven by an increase in the area planted with potatoes, which have a lower CCWP.
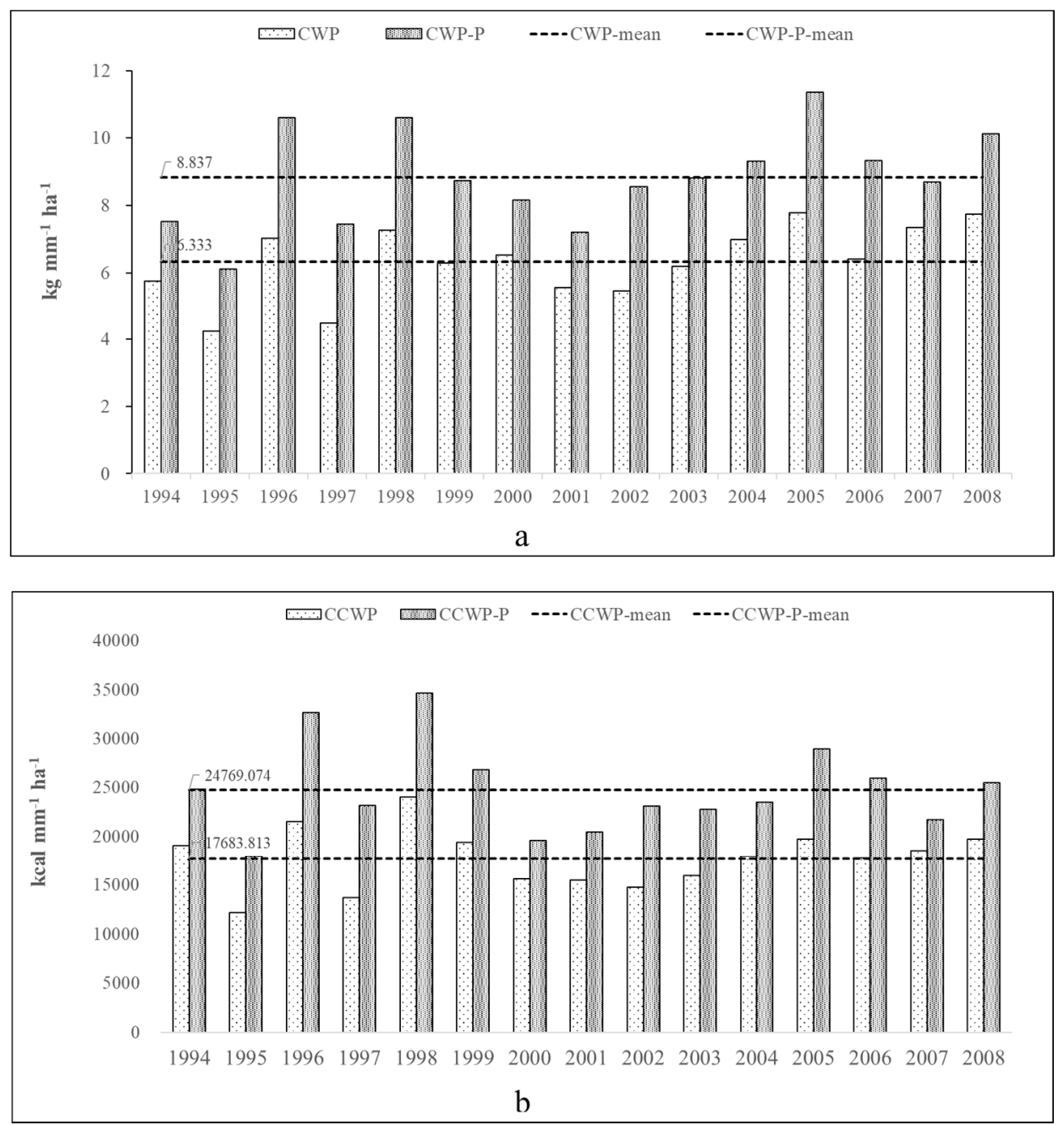

Figure 6. Annual changes from 1994 to 2008 in (a) the green water crop productivity (CWP) and productive green water crop productivity (CWP-P) in the study area and (b) changes in the corresponding caloric productivities (CCWP and CCWP-P). Horizontal dashed lines represent the mean parameter value during the study period.

\subsection{Comparison of CWP of Agricultural Systems between Counties}

Figure 7a shows the changes in CWP and CWP-P in the four counties during the study period, and Table 8 provides the data used to create this figure. Figure $7 \mathrm{~b}$ shows considerable variation among the counties, with a mean CWP ranging from $5.760 \mathrm{~kg} \mathrm{~mm}^{-1} \mathrm{ha}^{-1}$ in Ansai County to 
$7.715 \mathrm{~kg} \mathrm{~mm}^{-1} \mathrm{ha}^{-1}$ in Wuqi County, and mean a CWP-P ranging from $8.084 \mathrm{~kg} \mathrm{~mm}^{-1} \mathrm{ha}^{-1}$ in Ansai county to $10.743 \mathrm{~kg} \mathrm{~mm}^{-1} \mathrm{ha}^{-1}$ in Wuqi County.
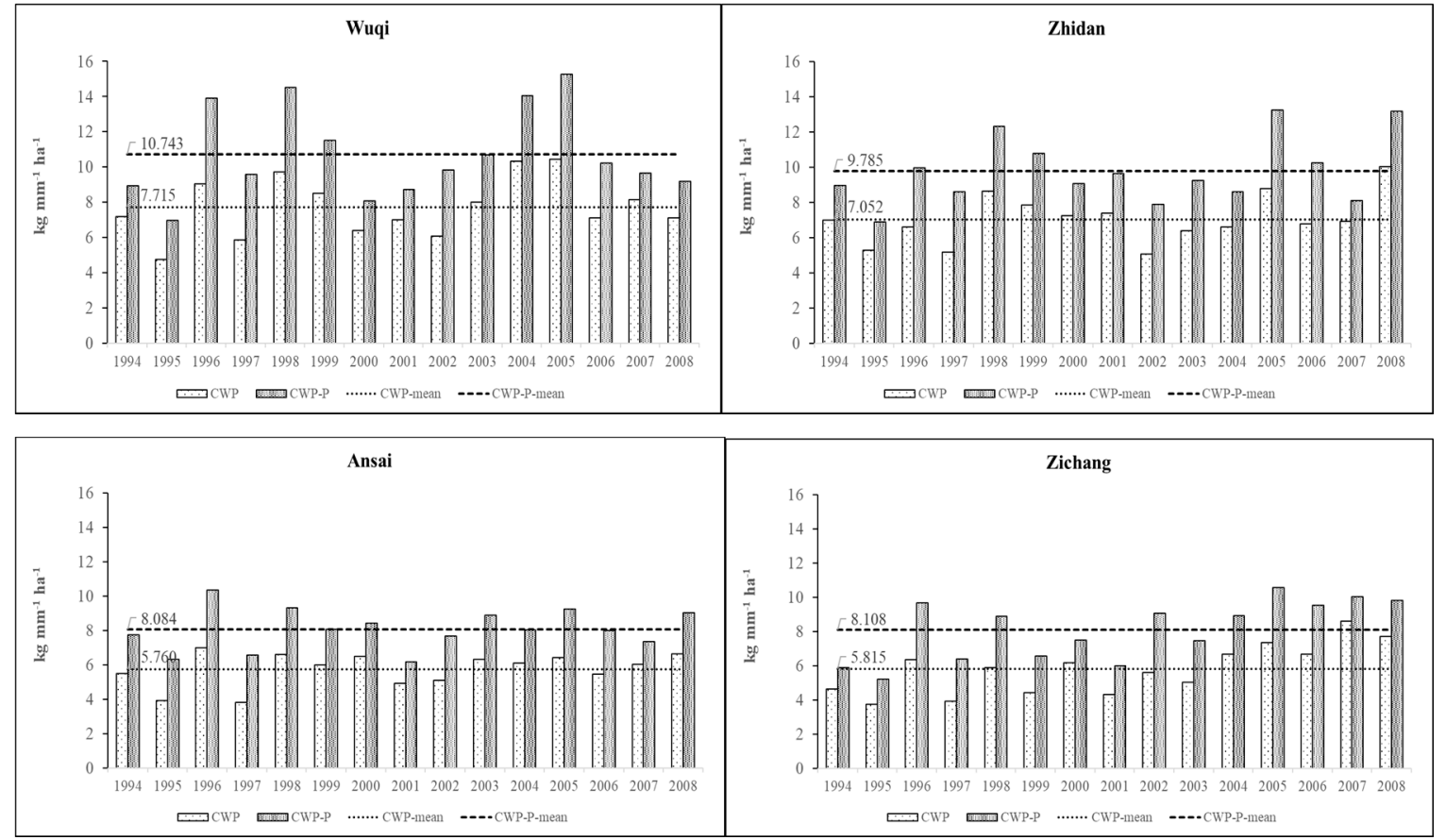

(a)

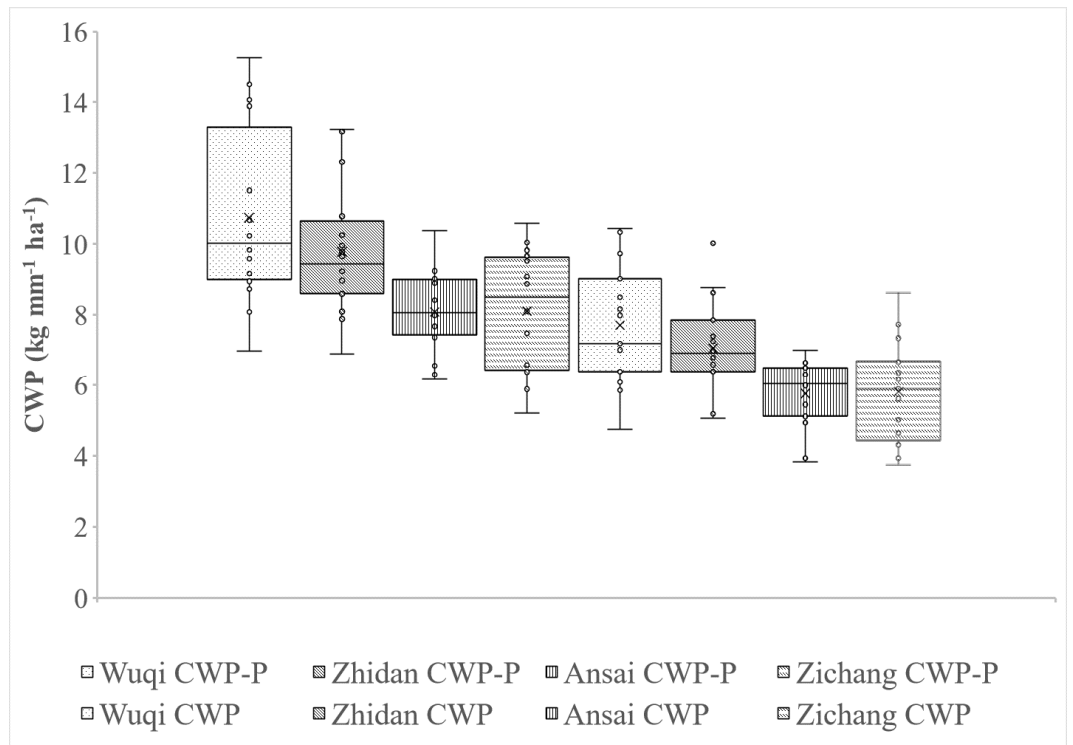

(b)

Figure 7. (a): Annual changes from 1994 to 2008 in green water crop productivity (CWP) and productive green water crop productivity (CWP-P) in the four counties. Horizontal dashed lines represent the mean parameter value during the study period. (b): Distribution of CWP and CWP-P values for each county. Box-plot description: Horizontal lines represent means, bars represent the 25th to 75th percentiles, range bars represent the maximum and minimum values, and dots outside this range represent outliers. 
Table 8. Green water crop productivity (CWP) and productive green water crop productivity (CWP-P) of the four counties during the study period.

\begin{tabular}{|c|c|c|c|c|c|c|c|c|c|c|c|c|c|c|c|c|c|}
\hline County & & 1994 & 1995 & 1996 & 1997 & 1998 & 1999 & 2000 & 2001 & 2002 & 2003 & 2004 & 2005 & 2006 & 2007 & 2008 & Mean \\
\hline \multirow{2}{*}{ Wuqi } & CWP & 7.198 & 4.759 & 9.029 & 5.850 & 9.733 & 8.507 & 6.396 & 7.015 & 6.088 & 7.993 & 10.339 & 10.441 & 7.110 & 8.163 & 7.104 & 7.715 \\
\hline & CWP-P & 8.950 & 6.983 & 13.894 & 9.596 & 14.505 & 11.519 & 8.086 & 8.726 & 9.834 & 10.684 & 14.067 & 15.251 & 10.232 & 9.641 & 9.173 & 10.743 \\
\hline \multirow{2}{*}{ Zhidan } & CWP & 6.990 & 5.300 & 6.600 & 5.188 & 8.630 & 7.855 & 7.255 & 7.401 & 5.056 & 6.405 & 6.596 & 8.770 & 6.787 & 6.917 & 10.034 & 7.052 \\
\hline & CWP-P & 8.974 & 6.900 & 9.963 & 8.598 & 12.315 & 10.788 & 9.079 & 9.653 & 7.887 & 9.239 & 8.613 & 13.246 & 10.253 & 8.100 & 13.170 & 9.785 \\
\hline \multirow{2}{*}{ Ansai } & CWP & 5.495 & 3.936 & 7.011 & 3.828 & 6.607 & 5.994 & 6.501 & 4.943 & 5.117 & 6.307 & 6.095 & 6.431 & 5.449 & 6.042 & 6.648 & 5.760 \\
\hline & CWP-P & 7.761 & 6.319 & 10.374 & 6.562 & 9.316 & 8.083 & 8.415 & 6.168 & 7.681 & 8.898 & 8.051 & 9.243 & 7.993 & 7.368 & 9.033 & 8.084 \\
\hline \multirow{2}{*}{ Zichang } & CWP & 4.652 & 3.757 & 6.369 & 3.932 & 5.900 & 4.437 & 6.167 & 4.319 & 5.614 & 5.017 & 6.676 & 7.348 & 6.682 & 8.622 & 7.731 & 5.815 \\
\hline & CWP-P & 5.888 & 5.208 & 9.678 & 6.387 & 8.884 & 6.581 & 7.497 & 5.995 & 9.087 & 7.475 & 8.947 & 10.581 & 9.528 & 10.055 & 9.829 & 8.108 \\
\hline \multirow{2}{*}{$\begin{array}{l}\text { Weighted } \\
\text { average }\end{array}$} & CWP & 5.755 & 4.239 & 7.019 & 4.490 & 7.263 & 6.287 & 6.521 & 5.532 & 5.426 & 6.193 & 6.993 & 7.785 & 6.404 & 7.342 & 7.740 & 6.333 \\
\hline & CWP-P & 7.516 & 6.106 & 10.603 & 7.436 & 10.602 & 8.729 & 8.169 & 7.206 & 8.553 & 8.816 & 9.317 & 11.356 & 9.338 & 8.695 & 10.120 & 8.837 \\
\hline
\end{tabular}


Figure 8 shows the corresponding CCWP and CCWP-P values. Table 9 presents the data used to create these graphs. The caloric productivity (Figure 8) showed variation similar to that for CWP and CWP-P, with CCWP ranging from 14,622.19 $\mathrm{kcal} \mathrm{mm}^{-1} \mathrm{ha}^{-1}$ in Zhichang County to $22,771.81 \mathrm{kcal} \mathrm{mm}^{-1} \mathrm{ha}^{-1}$ in Zhidan County and CCWP-P ranging from 20,617.38 $\mathrm{kcal} \mathrm{mm}^{-1} \mathrm{ha}^{-1}$ in Zhichang County to $31,542.23 \mathrm{kcal} \mathrm{mm}^{-1} \mathrm{ha}^{-1}$ in Zhidan County.
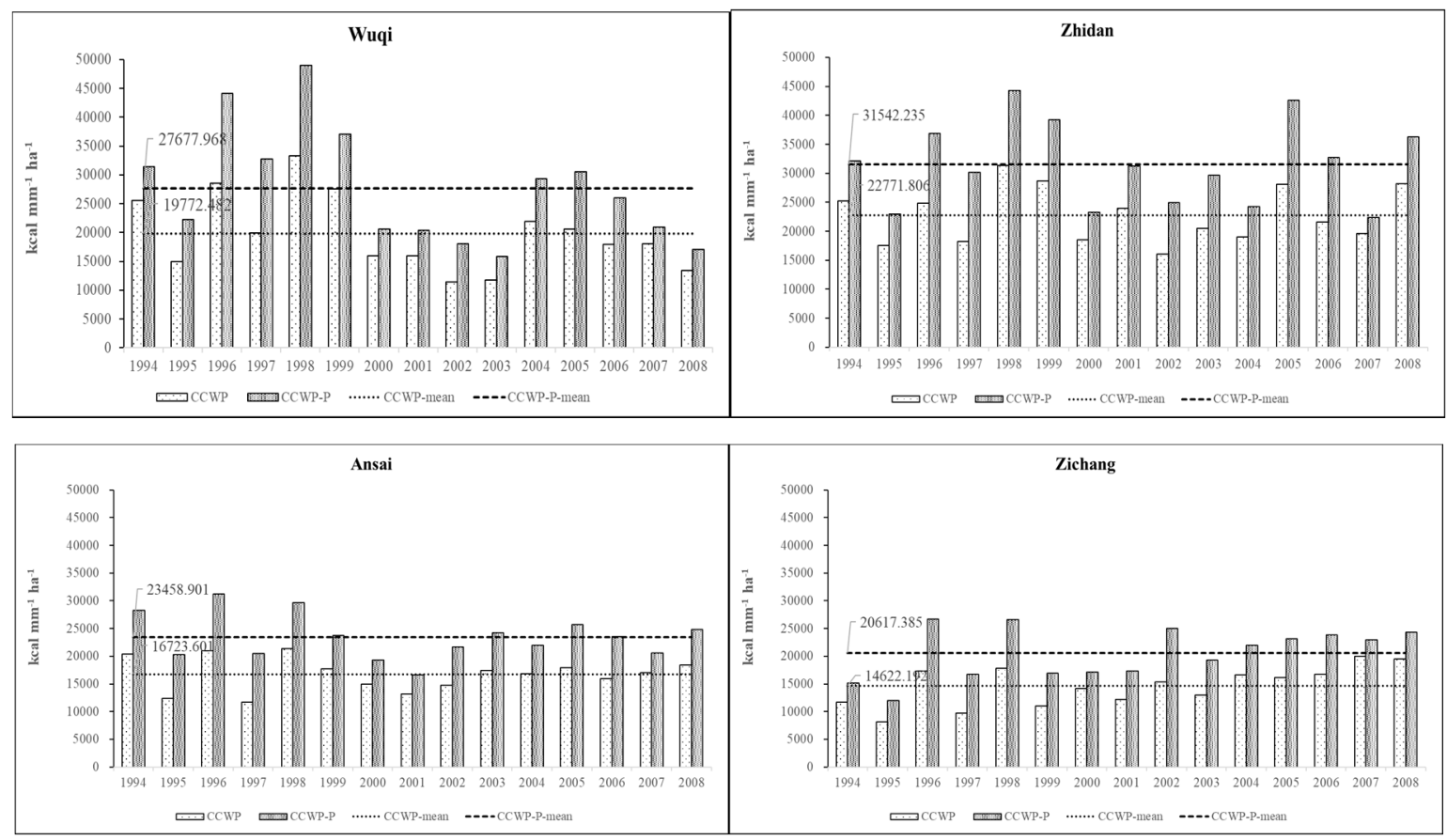

Figure 8. Annual changes from 1994 to 2008 in green water caloric crop productivity (CCWP) and productive green water caloric crop productivity (CCWP-P) in the four counties. Horizontal dashed lines represent the mean parameter value during the study period. 
Table 9. Green water caloric crop productivity (CCWP, $\mathrm{kcal} \mathrm{mm}^{-1} \mathrm{ha}^{-1}$ ) and productive green water caloric crop productivity (CCWP-P, $\mathrm{kcal} \mathrm{mm}^{-1} \mathrm{ha}^{-1}$ ) of the four counties during the study period.

\begin{tabular}{|c|c|c|c|c|c|c|c|c|c|c|c|c|c|c|c|c|c|}
\hline County & & 1994 & 1995 & 1996 & 1997 & 1998 & 1999 & 2000 & 2001 & 2002 & 2003 & 2004 & 2005 & 2006 & 2007 & 2008 & Mean \\
\hline \multirow{2}{*}{ Wuqi } & & & & & & 75 & & & 67 & 55 & 88 & & & 31 & 52 & 50 & 2.48 \\
\hline & & & & & 69 & 55 & & & & 67 & & & & & & & .97 \\
\hline \multirow[b]{2}{*}{ Zhidan } & & & 0 & 68 & 78 & 31 & .54 & .53 & $23,972.67$ & 59 & $20,492.65$ & 48 & 28, & 21, & $19,578.62$ & $28,232.75$ & 22 \\
\hline & & & & 36,8 & 0 & & 279.23 & 23,2 & 42 & 24,9 & 24 & & & & & 36,3 & \\
\hline \multirow[b]{2}{*}{ Ansai } & & $20,359.21$ & 9 & 2 & $11,662.42$ & 9 & 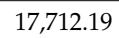 & $x$ & 00 & S & $1 ?$ & $16,813.15$ & $17,935.84$ & 1 & 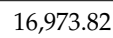 & 2 & 60 \\
\hline & ten & & 57 & 31 & 30 & 29,6 & 23,6 & 19,2 & $16,616.18$ & $21,640.07$ & $24,264.74$ & 21 & .34 & 23,4 & 20,5 & 24,8 & \\
\hline \multirow{2}{*}{ Zichang } & & & 8187.24 & & & & & & & & & & & & & & \\
\hline & CCWP-P & 85 & $11,987.01$ & $26,720.47$ & $16,709.78$ & $26,607.20$ & $16,893.87$ & $17,168.42$ & $17,362.91$ & $25,028.96$ & $19,326.97$ & $22,001.41$ & $23,156.59$ & $23,781.15$ & $22,966.51$ & $24,363.69$ & $20,617.39$ \\
\hline \multirow{2}{*}{$\begin{array}{c}\begin{array}{c}\text { Weighted } \\
\text { average }\end{array} \\
\text {. }\end{array}$} & & & & & & & & & & & & & & & & & \\
\hline & CCWP-P & 39 & 3.84 & 32,6 & $23,194.04$ & $34,602.15$ & $26,842.40$ & 19,61 & $20,478.06$ & 23,07 & 22,7 & & & 25,9 & 21,6 & & 24,7 \\
\hline
\end{tabular}


CWP and CWP-P differed significantly among the counties (Table 10). For both CWP and CWP-P, Wuqi and Zhidan counties had the highest values, but did not differ significantly. Ansai and Zichang had the loewst values, and did not differ significantly. Similar to CWP and CWP-P, for both CCWP and CCWP-P, Wuqi and Zhidan counties had the highest values, and did not differ significantly. Ansai and Zichang had the lowest values, and did not differ significantly either.

Table 10. Average crop water productivity (CWP) and productive crop water productivity (CWP-P) in the four counties during the study period. Values of a parameter labeled with the same letter do not differ significantly (two-sided t-test, $p<0.05$ ). The weighted averages were based on the total cultivated area in each county.

\begin{tabular}{ccccc}
\hline & CWP & CWP-P & CCWP & CCWP-P \\
\hline Wuqi & $7.715 \mathrm{a}$ & $10.743 \mathrm{c}$ & $19,772.48 \mathrm{a}$ & $27,677.97 \mathrm{c}$ \\
Zhidan & $7.052 \mathrm{a}$ & $9.785 \mathrm{c}$ & $22,771.81 \mathrm{a}$ & $31,542.23 \mathrm{c}$ \\
Ansai & $5.76 \mathrm{~b}$ & $8.084 \mathrm{~d}$ & $16,723.60 \mathrm{~b}$ & $23,458.90 \mathrm{~d}$ \\
Zichang & $5.815 \mathrm{~b}$ & $8.108 \mathrm{~d}$ & $14,622.19 \mathrm{~b}$ & $20,617.39 \mathrm{~d}$ \\
Weighted-average CWP & 6.333 & 8.837 & $17,683.81$ & $24,769.07$ \\
\hline
\end{tabular}

\subsection{Changes in Crop Area during the Study Period}

The areas cultivated with the nine crops changed from 1994 to 2008 (Figure 9). The area of wheat, which had a consistently low CWP, decreased rapidly after 1998, whereas the areas of corn and sorghum, which had a consistently high CWP, remained relatively stable. The area of potato, which had the worst CCWP, generally increased throughout the study period. These results demonstrate that from the perspective of improving the efficiency of water use, there is still room for optimization of the crop planting structure. For example, if all of the potatoes were replaced with corn, the same amount of water could produce $45 \times 10^{6} \mathrm{kcal}_{\text {year }}-1$ more calories; alternatively, the same calories could be produced using 21,000 $\mathrm{t}$ less water.

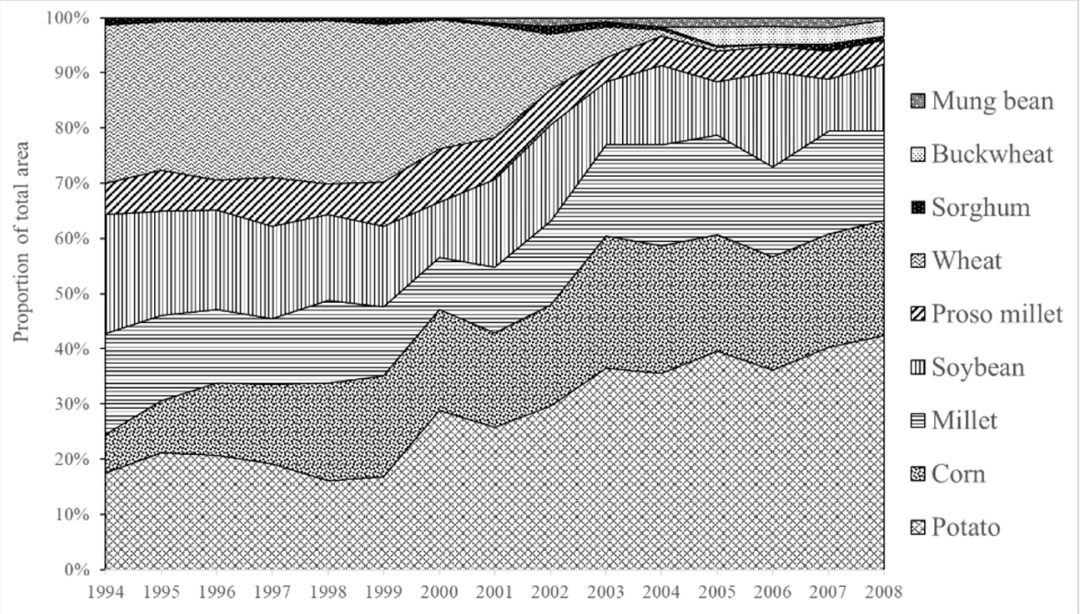

Figure 9. Changes in the proportion of the total area cultivated with the nine major crops from 1994 to 2008 .

Table 11 presents the statistical characteristics of the CWP and CWP-P values for the nine crops during the study period. Corn had the highest mean CWP and CWP-P values, followed by sorghum, whereas millet and mung bean had the lowest values. However, sorghum had the highest variation in CWP and CWP-P, followed by corn, and buckwheat and mung bean had the lowest variation. Both the mean yield and its variation should be carefully considered during plans to increase the water-use efficiency, since some crops with high yield may lose that advantage in unusually dry or warm years. 
This is a particular concern due to the drying and warming trend that is accompanying global warming in many areas.

Table 11. Statistical characteristics of the crop water productivity (CWP) and productive crop water productivity (CWP-P) for the nine crops during the study period.

\begin{tabular}{|c|c|c|c|c|c|c|}
\hline \multirow[b]{2}{*}{ Crops } & \multicolumn{3}{|c|}{ CWP $\left(\mathrm{kg} \mathrm{mm}^{-1} \mathrm{ha}^{-1}\right)$} & \multicolumn{3}{|c|}{ CWP-P $\left(\mathrm{kg} \mathrm{mm}^{-1} \mathrm{ha}^{-1}\right)$} \\
\hline & Mean & $\begin{array}{c}\text { Standard } \\
\text { Deviation }\end{array}$ & $\begin{array}{l}\text { Coefficent } \\
\text { of Variation }\end{array}$ & Mean & $\begin{array}{l}\text { Standard } \\
\text { Deviation }\end{array}$ & $\begin{array}{l}\text { Coefficent } \\
\text { of Variation }\end{array}$ \\
\hline Potato & 7.043 & 1.227 & 0.174 & 9.496 & 1.690 & 0.177 \\
\hline Corn & 12.370 & 1.964 & 0.159 & 16.215 & 2.772 & 0.171 \\
\hline Millet & 4.211 & 1.199 & 0.285 & 5.329 & 1.476 & 0.277 \\
\hline Soybean & 4.291 & 1.203 & 0.280 & 5.475 & 1.602 & 0.293 \\
\hline Millet & 4.139 & 1.219 & 0.294 & 5.225 & 1.313 & 0.251 \\
\hline Wheat & 3.570 & 1.188 & 0.332 & 8.505 & 2.679 & 0.315 \\
\hline Sorghum & 9.152 & 3.406 & 0.372 & 11.797 & 3.797 & 0.322 \\
\hline Buckwheat & 4.829 & 0.531 & 0.110 & 10.183 & 1.083 & 0.106 \\
\hline Mung bean & 3.329 & 0.544 & 0.164 & 4.608 & 0.830 & 0.180 \\
\hline
\end{tabular}

\section{Discussion}

Understanding CWP and CCWP at the levels of individual crops and specific regions has important practical significance for local food production and for adjusting the crop structure to promote more sustainable use of limited water resources. By combining meteorological data with crop data, we assessed the green water consumption of the nine main food crops in a representative region of China's Loess Plateau and calculated the crop and caloric crop water productivity that resulted from the region's use of green water. Our results showed that although average CWP and CCWP values in Northern Shaanxi Province varied significantly over time, there was no consistent trend.

We found that CWP was highest for corn, sorghum, and potato; however potato had the lowest CCWP of all crops, suggesting the importance of considering CWP based on more than just gross yield. We found significant differences in both CWP and CCWP among the four counties, with Wuqi (with annual average precipitation of $422.158 \mathrm{~mm}$ ) and Zhidan $(453.64 \mathrm{~mm})$ consistently having higher productivities than Ansai $(455.675 \mathrm{~mm}$ ) and Zichang $(444.01 \mathrm{~mm})$. The possible causes of lower CWP or CCWP may be the larger area and proportion of crops with lower CWP or CCWP, such as Zichang with the lager area $(80,116 \mathrm{ha})$ and larger proportion $(18.25 \%)$ of wheat. Additionally, Zichang had the larger area $(15,8554 \mathrm{ha})$ and the larger proportion $(36.12 \%)$ of potatoes. Our results suggest that, without considering economic factors such as food prices, corn and sorghum should be the two preferred options based on their green water productivity because they combine high productivity (in terms of both yield and calories) with efficient water use, thereby making better use of the region's limited water resources. While corn and sorghum are the two crops with the highest CWP, they differ considerably in the interannual variability of both CWP and CWP-P; sorghum's coefficient of variation was more than twice that of corn for CWP, and the difference was nearly as large for CWP-P. This suggests that corn not only has among the highest water productivity of the crops we studied, but also the highest stability in yield.

\subsection{Comparison with Previous Research}

Our work responds to several previous studies. Previous CWP research mainly focused on large-scale assessments and single (or few) crops. In terms of large-scale research, extensive research has provided a good foundation for the macroscopic understanding of agricultural water resources and their production efficiency. For example, Kaneko et al. [35] applied stochastic frontier analysis to provincial-level data to measure the water-use efficiency in China's agricultural production from 1999 to 2002, and found that corn was the most important crop in terms of improving both economic and water efficiency. Our results, which cover a smaller area, but over a longer time period, corroborate 
Kaneko's findings: Corn was among the crops with the highest water productivity, and also had low variability in that yield. Wu et al. studied regional differences in CWP around the world from 1990 to 2007 based on data from 87 countries and listed key factors on which countries with low water-use efficiency should focus in order to improve crop yield and reduce its regional variation [36].

In terms of research on individual crops, previous studies revealed the CWP of specific crops in an effort to provide a good basis for comprehensive understanding of regional food CWP. A comprehensive analysis of 39 datasets from experiments spanning 20 years showed that the CWP of dry-land wheat in the Loess Plateau ranged from 3.4 to $23.4 \mathrm{~kg} \mathrm{ha}^{-1} \mathrm{~mm}^{-1}$ [3]. Our estimates of wheat CWP are on the low end of this range, as they never exceeded $5.159 \mathrm{~kg} \mathrm{ha}^{-1} \mathrm{~mm}^{-1}$, and fell below $3.4 \mathrm{~kg} \mathrm{ha}^{-1} \mathrm{~mm}^{-1}$ on multiple occasions. Zhang et al. [37] studied how the CWP of dryland corn in China's Loess Plateau responded to crop management and found that CWP ranged from 2.8 to $39.0 \mathrm{~kg} \mathrm{ha}^{-1} \mathrm{~mm}^{-1}$. While our CWP estimates for corn never approached the highest end of this range, they also consistently exceeded the lowest values from Zhang et al. study. The reason for the CWP difference is that Zhang's study mainly focuses on distinguishing the CWP of maize and wheat under different management measures, and this study aims at the average level of maize overall.

This previous research provides important perspectives on CWP at both the regional and single-crop scales. Combined with the county-scale study of nine crops in the present study, our research provides a more comprehensive understanding of CWP in the Loess Plateau. By identifying crops, such as potato, that use water inefficiently when viewed from a caloric perspective, regional agricultural leaders can determine which crops use water inefficiently and which should be replaced with more efficient crops.

\subsection{Additions to Previous Research}

The present study provides four new contributions to the literature on crop water-use efficiency.

First, we demonstrated the applicability of our method at a scale intermediate between those of previous small-scale studies (e.g., individual crops or fields) and large-scale studies (e.g., provinces). Our CWP and CCWP assessments for green water productivity of nine main crops at a county level provide important reference values to improve our understanding of how to optimize water use in the Loess Plateau's rain-fed agricultural systems by identifying the most and least efficient crops. In contrast with previous site-specific research, crop-specific research, and assessments at large scales, the present study permits calculations at a scale similar to that at which crops are managed, for regions with relatively consistent climate conditions. As a result, it will promote more effective use of the Loess Plateau's limited water resources.

Second, our study shows the applicability of our method to studying CWP of agricultural systems in the developing world. Our method is much less expensive and time-consuming than field surveys, and is therefore more suitable for adoption over large areas such as the Loess Plateau. Because it does not require sophisticated and expensive techniques, it should be easily applicable to other arid and semi-arid regions of the world where researchers may lack resources to determine CWP based on field-based studies. This method is of particular importance to semi-arid regions, where high interannual variability in rainfall means that single-year studies of CWP may be misleading; long time scales are necessary to capture the variation that occurs in any farming region. Increasing the refinement of remote sensing technology has greatly promoted the evaluation of agricultural water resources [38]. While remote sensing technology is far superior to the method used in this study in terms of coverage area and data quantity, the method described in the present study has superior ability to account for different crop mixtures, which can be difficult to accomplish with remote sensing data due to the low spatial and temporal resolution of large-area datasets.

Third, our study focused on both the use and the productive use of green water. The latter is particularly important because it provides more ability to distinguish between crops in their CWP. By extending this analysis to the caloric value of the crops, our research also provides important support for analyses of food security. 
Fourth, our approach links CWP and CCWP with the hydrological cycle processes that control crop production. It will therefore provide insights that will help to optimize the use of the region's limited water resources, thereby making it easier to combat poverty by improving livelihoods while also improving ecological protection.

\subsection{Limitations of Our Study and Directions for Future Research}

Our choice of study sites represented sites with typical characteristics for the study area. However, we could not account for all of the variation in sites within such a large region. Moreover, our use of interpolated meteorological data instead of site-specific data introduces some inaccuracy into our estimates; despite these limitations, our study used the finest-scale meteorological data currently available over an extended time. In future research, it would be beneficial to find ways to obtain site-specific meteorological data. While the values of the various model parameters that we used (e.g., the crop coefficients, the timing and duration of the growth periods) were the best available estimates at the time of our research, such parameters are dynamic, and in future research they may need be modified based on empirical data to more closely reflect the characteristics of our crops and study area.

While the counties, crops, and dataset we used in this study are representative of the semi-arid regions of China's Loess Plateau, they cover a relatively small part of the plateau and do not fully capture all of the climatic and other variation. Thus, it will be necessary to acquire more extensive data to permit the evaluation of CWP and CCWP on larger spatial scales. As there are differences in the availability of crop data and in data quality (e.g., continuity, integrity) among administrative regions, collecting this data will be a significant challenge. Further expansion of the scope of access to official statistics, possibly combined with the use of site-specific field data and remote sensing data, may overcome problems of data availability by expanding the scope and amount of the available data.

\section{Conclusions}

A comprehensive understanding of the water productivities of different crops is important to the efficient use of water resources in water-scarce regions such as China's Loess Plateau. This paper evaluates the consumption of green water in nine primary crops grown in Northern Shaanxi by estimating of evapotranspiration based on daily meteorological data. By combining meteorological data with crop yields data, the CWP, CWP-P, CCWP and CCWP-P of different crops had been evaluated. It was found that the regional averaged CWP was $6.333 \mathrm{~kg} \mathrm{~mm}^{-1} \mathrm{ha}^{-1}$ and the CCWP was 17,683.81 cal mm ${ }^{-1} \mathrm{ha}^{-1}$. Corn, sorghum, and buckwheat had the highest value of CWP. Corn had low variability in yield and the highest water productivity among the nine crops. Potato, which is among the crops with the largest acreage in the research area has very low CCWP, despite having a relatively high CWP. This difference illustrates the importance of considering multiple measure of crop water productivity, as results may vary. In our study we evaluated caloric and gross CWP, however future research could also consider economic CWP measured in the value of crop sold per unit of evapotranspiration. We identified some differences in both CWP and CCWP among the four counties. This research provides three new contributions to the literature on CWP: (1) We calculated CWP on the Loess Plateau at a mesoscale of county-level in contrast to previous field-level or global and national calculations; (2) We illustrated a new method of estimation that is less expensive than field surveys; and (3) This method has some advantages in distinguishing between the CWP different crops. Future research will focus on expanding research areas on the Loess Plateau, which would allow for the use of spatial analysis, and combining other data sources such as field surveys and remote sensing.

Author Contributions: A.C.-S. directed the data analysis. J.M. and J.Q. provided guidance on the research topics and methods, and revised the article. J.W. wrote the article. 
Funding: This study was funded under the research project “Evaluating the Impact of Green Water Management Strategies on Crop Water Productivity" by a grant from the National Natural Science Foundation of China (grant number 41550110227).

Acknowledgments: The authors thank Zou Tao of the Yantai Institute of Coastal Zone Research, Chinese Academy of Sciences, and Ms. Liu Yanfei of the Lanzhou Information Center, Chinese Academy of Sciences, for their help in obtaining the meteorological data. We thank Tang Xia, Northwest Institute of Eco-Environmental and Resources, Chinese Academy of Sciences, and Professor Zhu Gaofeng, Wang Shangtao and Chen Huiling, College of Earth and Environment Sciences, Lanzhou University, for discussion of the data calculation methods. We also thank Ma Hanqing, Northwest Institute of Eco-environmental Resources, Chinese Academy of Sciences, and Wang Lin, School of Architecture, Hua Qiao University, for their advice on the structure of the article.

Conflicts of Interest: The authors declare no conflict of interest.

\section{References}

1. Hoff, H.; Falkenmark, M.; Gerten, D.; Gordon, L.; Karlberg, L.; Rockstrom, J. Greening the global water system. J. Hydrol. 2010, 384, 177-186. [CrossRef]

2. Debaeke, P.; Aboudrare, A. Adaptation of crop management to water-limited environments. Eur. J. Agron. 2004, 21, 433-446. [CrossRef]

3. Zhang, S.; Sadras, V.; Chen, X.; Zhang, F. Water use efficiency of dryland wheat in the loess plateau in response to soil and crop management. Field Crops Res. 2013, 151, 9-18. [CrossRef]

4. Li, S. Chinese Dryland Agriculture; Chinese Press of Agriculture: Beijing, China, 2004.

5. Deng, X.P.; Shan, L.; Zhang, H.P.; Turner, N.C. Improving agricultural water use efficiency in arid and semiarid areas of China. Agric. Water Manag. 2006, 80, 23-40. [CrossRef]

6. Hu, C.; Ding, M.; Qu, C.; Sadras, V.; Yang, X.; Zhang, S. Yield and water use efficiency of wheat in the loess plateau: Responses to root pruning and defoliation. Field Crops Res. 2015, 179, 6-11. [CrossRef]

7. Smedema, L.K.; Shiati, K. Irrigation and salinity: A perspective review of the salinity hazards of irrigation development in the arid zone. Irrig. Drain. Syst. 2002, 16, 161-174. [CrossRef]

8. Schmautz, Z.; Loeu, F.; Liebisch, F.; Graber, A.; Mathis, A.; Bulc, T.G.; Junge, R. Tomato productivity and quality in aquaponics: Comparison of three hydroponic methods. Water 2016, 8, 533. [CrossRef]

9. Clarke-Sather, A.; Tang, X.; Xiong, Y.; Qu, J. The impact of green water management strategies on household-level agricultural water productivity in a semi-arid region: A survey-based assessment. Water 2018, 10, 11. [CrossRef]

10. Nangia, V.; de Fraiture, C.; Turral, H. Water quality implications of raising crop water productivity. Agric. Water Manag. 2008, 95, 825-835. [CrossRef]

11. Hoekstra, A.Y.; Mekonnen, M.M. The water footprint of humanity. Proc. Natl. Acad. Sci. USA 2012, 109, 3232-3237. [CrossRef] [PubMed]

12. Rost, S.; Gerten, D.; Hoff, H.; Lucht, W.; Falkenmark, M.; Rockstrom, J. Global potential to increase crop production through water management in rainfed agriculture. Environ. Res. Lett. 2009, 4, 1-9. [CrossRef]

13. Aldaya, M.M.; Allan, J.A.; Hoekstra, A.Y. Strategic importance of green water in international crop trade. Ecol. Econ. 2010, 69, 887-894. [CrossRef]

14. Li, B.; Huang, F. Trends in China's agricultural water use during recent decade using the green and blue water approach. Adv. Water Sci. 2010, 21, 575-583.

15. Wang, Y.J.; Xie, Z.K.; Malhi, S.S.; Vera, C.L.; Zhang, Y.B.; Wang, J.N. Effects of rainfall harvesting and mulching technologies on water use efficiency and crop yield in the semi-arid loess plateau, China. Agric. Water Manag. 2009, 96, 374-382. [CrossRef]

16. Yan, W.M.; Zhong, Y.Q.W.; Zheng, S.X.; Shangguan, Z.P. Linking plant leaf nutrients/stoichiometry to water use efficiency on the loess plateau in China. Ecol. Eng. 2016, 87, 124-131. [CrossRef]

17. Vaghefi, S.A.; Abbaspour, K.C.; Faramarzi, M.; Srinivasan, R.; Arnold, J.G. Modeling crop water productivity using a coupled swat-modsim model. Water 2017, 9, 157. [CrossRef]

18. Sun, C.; Ren, L. Assessing crop yield and crop water productivity and optimizing irrigation scheduling of winter wheat and summer maize in the haihe plain using swat model. Hydrol. Processes 2014, 28, 2478-2498. [CrossRef]

19. Najafi, P.; Tabatabaei, S.H. Effect of using subsurface drip irrigation and et-hs model to increase wue in irrigation of some crops. Irrig. Drain. 2007, 56, 477-486. [CrossRef] 
20. Allen, R.G.; Pereira, L.S. Estimating crop coefficients from fraction of ground cover and height. Irrig. Sci. 2009, 28, 17-34. [CrossRef]

21. Allen, R.G.; Pereira, L.S.; Smith, M.; Raes, D.; Wright, J.L. FAO-56 dual crop coefficient method for estimating evaporation from soil and application extensions. J. Irrig. Drain. Eng. 2005, 131, 2-13. [CrossRef]

22. Administration, C.M. Specification for Ground Meteorological Observations; China Meteorological Press: Beijing, China, 2003.

23. Lu, G.Y.; Wong, D.W. An adaptive inverse-distance weighting spatial interpolation technique. Comput. Geosci. 2008, 34, 1044-1055. [CrossRef]

24. Liu, G.; Wang, Y.; Wang, Y. Impact of inverse distance weighted interpolation factors on interpolation error. China Sciencepaper 2010, 5, 879-884.

25. Liang, Y.; Liu, A.; Xing, Q.; Chang, S. Application of inverse distance weighted interpolation in monitoring of inner Mongolia's natural grassland vegetation cover. Grassland Inner Mongolia 2009, 21, 2-3.

26. Gao, X. Statistical Yearbook of Yan'an; Xi'an Press: Yan'an, China, 2008.

27. Allen, R.G.; Pereira, L.S.; Raes, D.; Smith, M. Fao Irrigation and Drainage Paper No. 56. Available online: https:/ / www.kimberly.uidaho.edu/water/fao56/fao56.pdf (accessed on 22 August 2018).

28. Yan, H.; Zhang, C.; Oue, H.; Wang, G.; He, B. Study of evapotranspiration and evaporation beneath the canopy in a buckwheat field. Theor. Appl. Climatol. 2015, 122, 721-728. [CrossRef]

29. USDA. Usda Food Composition Databases. Available online: https://ndb.nal.usda.gov/ndb/ (accessed on 22 August 2018).

30. Fan, J.; Shao, M.; Wang, Q. Comparison of many equations for calculating reference evapotranspiration in the loess plateau of China. Trans. Chin. Soc. Agric. Eng. 2008, 24, 98-102.

31. Liu, X.; Lin, E.; Liu, P. Study on application of priestly-taylor method to dry climate condition. J. Hydraul. Eng. 2003, 9, 31-38.

32. FAO. Eto Calculator. Available online: http://www.fao.org/land-water/databases-and-software/etocalculator/es/ (accessed on 22 August 2018).

33. Rockström, J. On-farm Agrohydrological Analysis of the Sahelian Yield Crisis: Rainfall partitioning, Soil Nutrients and Water Use Efficiency of Pearl Millet. Ph.D. Thesis, Stockholm University, Stockholm, Sweden, 1997.

34. Rockstrom, J. On-farm green water estimates as a tool for increased food production in water scarce regions. Phys. Chem. Earth Part B 1999, 24, 375-383. [CrossRef]

35. Kaneko, S.; Tanaka, K.; Toyota, T.; Managi, S. Water efficiency of agricultural production in China: Regional comparison from 1999 to 2002. Int. J. Agric. Resour. Gov. Ecol. 2004, 3, 231-251. [CrossRef]

36. Wu, Z.; Zhao, M.; Lall, U. Regional difference of water use efficiency of crop production in the world: Analysis and suggestions. China Popul. Res. Environ. 2013, 23, 55-62.

37. Zhang, S.; Sadras, V.; Chen, X.; Zhang, F. Water use efficiency of dryland maize in the loess plateau of China in response to crop management. Field Crops Res. 2014, 163, 55-63. [CrossRef]

38. Shang, S.; Jiang, L.; Yang, Y. Review of remote sensing-based assessment method for irrigation and crop water use efficiency. Trans. Chin. Soc. Agric. Mach. 2015, 46, 81-92.

(C) 2018 by the authors. Licensee MDPI, Basel, Switzerland. This article is an open access article distributed under the terms and conditions of the Creative Commons Attribution (CC BY) license (http://creativecommons.org/licenses/by/4.0/). 